Review

\title{
An Overview of the Mechanisms Involved in Coffee-Hemileia vastatrix Interactions: Plant and Pathogen Perspectives
}

\author{
Maria do Céu Silva ${ }^{1,2} \mathbb{D}$, Leonor Guerra-Guimarães ${ }^{1,2, *(\mathbb{D}}$, Inês Diniz ${ }^{1,2, * \mathbb{D}}$, Andreia Loureiro ${ }^{1,2} \mathbf{D}^{\mathbb{D}}$, \\ Helena Azinheira 1,2 ${ }^{1}$, Ana P. Pereira ${ }^{1,2}\left(\mathbb{D}\right.$, Sílvia Tavares ${ }^{1,2,3}$, Dora Batista ${ }^{1,2}$ and Vítor Várzea ${ }^{1,2}$
}

1 CIFC - Centro de Investigação das Ferrugens do Cafeeiro, Instituto superior de Agronomia, Universidade de Lisboa, 2784-505 Oeiras, Portugal; mariaceusilva@isa.ulisboa.pt (M.d.C.S.); andreialoureiro@isa.ulisboa.pt (A.L.); hmga@edu.ulisboa.pt (H.A.); appereira@isa.ulisboa.pt (A.P.P.); satavares@isa.ulisboa.pt (S.T.); dorabatista@isa.ulisboa.pt (D.B.); vitorvarzea@isa.ulisboa.pt (V.V.)

2 LEAF-Linking Landscape, Environment, Agriculture and Food, Instituto Superior de Agronomia, Universidade de Lisboa, 1349-017 Lisboa, Portugal

3 Department of Plant and Environmental Sciences, Copenhagen Plant Science Center, University of Copenhagen, 1871 Frederiksberg C, Denmark

* Correspondence: leonorguimaraes@edu.ulisboa.pt (L.G.-G.); inesdiniz@isa.ulisboa.pt (I.D.)

\section{check for}

updates

Citation: Silva, M.d.C.;

Guerra-Guimarães, L.; Diniz, I.;

Loureiro, A.; Azinheira, H.; Pereira,

A.P.; Tavares, S.; Batista, D.; Várzea, V.

An Overview of the Mechanisms

Involved in Coffee-Hemileia vastatrix

Interactions: Plant and Pathogen

Perspectives. Agronomy 2022, 12, 326.

https://doi.org/10.3390/

agronomy 12020326

Academic Editor: Adrian C. Newton

Received: 30 December 2021

Accepted: 21 January 2022

Published: 26 January 2022

Publisher's Note: MDPI stays neutral with regard to jurisdictional claims in published maps and institutional affiliations.

Copyright: (C) 2022 by the authors. Licensee MDPI, Basel, Switzerland. This article is an open access article distributed under the terms and conditions of the Creative Commons Attribution (CC BY) license (https:// creativecommons.org/licenses/by/ $4.0 /)$.

\begin{abstract}
Coffee is one of the most consumed beverages in the world. It is also one of the most globally traded commodities. Coffee leaf rust (CLR), caused by the biotrophic fungus Hemileia vastatrix, is the most important disease affecting Arabica coffee growing worldwide, leading to significant yield losses if no control measures are applied. A deep understanding of the complex mechanisms involved in coffee- $H$. vastatrix interactions, such as the pathogen variability and the mechanisms governing plant resistance and susceptibility, is required to breed efficiently for durable resistance and design new approaches for crop protection. Here we summarize our current understanding across multiple areas related to pathogen infection, variability and candidate effectors, breeding for disease resistance, and the various components of the coffee immune system, by reviewing a comprehensive body of research on CLR and the advances recently made. We also update information about the defense responses activated by the application of plant resistance inducers, a promising alternative to fungicides in the control of CLR. Moreover, we identify and discuss future directions for further research.
\end{abstract}

Keywords: coffee leaf rust; rust variability; effectors; resistance; breeding; plant immunity; systemic acquired resistance

\section{Introduction}

Coffee is not only a vital presence in the daily life of a significant share of the world's population, with consumption of over 3 billion cups of coffee a day, it is also the most valuable primary product in world trade, crucial to the economy of more than 50 countries, and constitutes the main source of livelihood for up to 25 million farmers and their families [1]. Traditionally, coffee has been viewed as a tropical commodity that links growing countries in the global South, along the so-called "bean belt" that lies between the tropics of Cancer and Capricorn, with consuming countries in the global North.

Coffee belongs to the genus Coffea of the family Rubiaceae and consists of over 100 species [2,3]. The two main cultivated species, Coffea arabica L. (Arabica) and C. canephora Pierre ex A. Froehner (Robusta) accounted in 2020, on average, for about $60 \%$ and $40 \%$ of the world's coffee production, respectively [4]. Coffea liberica Bull ex Hiern (Liberian coffee), a third beverage species, is cultivated worldwide but is insignificant in terms of global trade [5]. 
Coffee leaf rust, caused by the biotrophic fungus Hemileia vastatrix Berkeley and Broome, is one of the main limiting factors of Arabica coffee production [6-9] causing production losses of over $\$ 1$ billion annually worldwide [10].

Since the 19th century historical first burst of CLR, which caused the eradication of coffee cultivation in Ceylon (now Sri Lanka), the disease spread through coffee-growing countries of Asia and Africa until 1950. In the Americas, CLR was first detected in Brazil in 1970 and dispersed progressively across the coffee plantations of other Latin American countries [11-13]. In Hawaii, CLR was reported for the first time in 2020 [14]. Nowadays, CLR is present in all the coffee growing regions. Furthermore, in the last decade, the epidemic resurgence of CLR known as "the big rust" impacted several countries across Latin America and the Caribbean on a level similar to the one observed in Ceylon [15-17]. This epidemic is causing losses of several hundred of million dollars, with extremely serious social consequences in the agricultural sector. It has been associated with changes in climatic conditions, the ecology of coffee farms, and recurring economic shocks $[15,16]$. Initially, there was some speculation that the epidemic might have been caused by the emergence of new, more aggressive rust races, but this hypothesis has not yet been confirmed [16,18].

$H$. vastatrix infects the lower surface of the leaves where it produces chlorotic spots preceding the differentiation of suprastomatal, bouquet-shaped, orange-coloured uredinia, leading to premature defoliation (Figure 1).

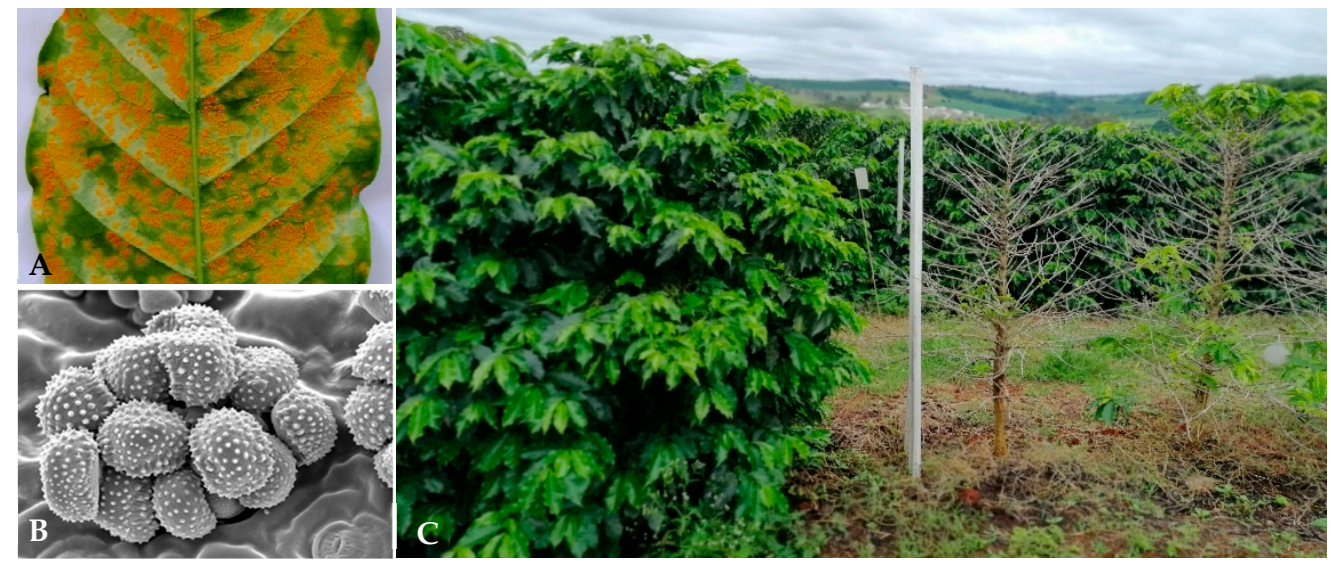

Figure 1. Coffee leaf rust symptoms and signs. (A) Chlorotic spots and uredosporic sori on the lower leaf surface; (B) an uredosporic sorum observed under the scanning electron microscope; (C) defoliation in coffee plants as a result of disease (right side), contrasting with resistant plants in the field (Brazil). Photos taken by the authors.

According to Rhiney et al. [18], defoliation is CLR's main effect, which reduces the plants' photosynthetic activity affecting the quantity of fruits and can influence coffee quality.

Coffee- $H$. vastatrix interactions are governed by the Flor's gene-for-gene relationship, and the resistance of coffee plants is conditioned at least by nine major dominant genes $\left(\mathrm{S}_{\mathrm{H}} 1-\mathrm{S}_{\mathrm{H}} 9\right)$ singly or associated $[11,19,20]$, although other major and minor genes may also be involved [11,21,22]. The use of coffee-resistant varieties is considered the most sustainable, efficient, and eco-friendly strategy to control this disease. Nevertheless, to improve the efficiency of the breeding process it is crucial to deepen our understanding of the complex mechanisms involved in the plant-pathogen interactions.

Plants have evolved highly complex defense mechanisms to protect themselves from various pathogens, with outcomes ranging from complete immunity, so called natural resistance or nonhost resistance, to susceptibility $[23,24]$. In addition to passive mechanisms, which include many preformed barriers such as waxy cuticles, rigid cell walls, and antimicrobial secondary metabolites [25], plants have evolved at least two lines of active defenses [26,27]. The first line provides basal defense against all potential pathogens and is based on the recognition of conserved microbe-associated or pathogen-associated molecular 
patterns (MAMPs/PAMPs) and host danger-associated molecular patterns (DAMPs), by pattern recognition receptors (PRRs) that activate PAMP-triggered immunity (PTI). Plants PRRs are either surface-localized receptor kinases (RKs) or receptor-like proteins (RLPs) containing various ligand-binding ectodomains that perceive PAMPs. Importantly, PTI has the potential to fend off multiple microbes, pathogenic or not, due to the conserved nature of PAMPs (e.g., bacterial flagellin, fungal chitin) across species, genera, family, or class. Thus, PRRs can provide resistance to most nonadapted pathogens, as well as contribute to basal immunity during infection [28-30]. The second layer of defense is activated when a given pathogen-derived molecule, called "effector", is "specifically recognized" by plant receptor proteins encoded by R genes, resulting in effector-triggered immunity (ETI) that leads to fast and acute responses. Our understanding of ETI has evolved starting from the gene-for-gene theory [31], which describes the association between plants and their pathogens through the interaction of pathogen-derived avirulence (Avr) genes and plant-derived resistance $(\mathrm{R})$ genes [26,32].

$R$ genes mostly encode nucleotide-binding leucine-rich repeat receptor (NLRs) proteins. NLRs are modular proteins composed of several conserved domains that recognize effector proteins through different mechanisms. The direct recognition of the effectors by NLRs is described in the interaction between two flax NLRs and the rust Melampsora lini effectors [33]. In cases of indirect NLR-mediated effector recognition, either the NLR "guards" a host effector target and is activated upon detecting its molecular modification (the guard hypothesis), or a "sensor" NLR perceives the avirulent effector and activates a "helper" NLR that is responsible for triggering ETI [24,32].

Successful pathogens secrete effectors extracellularly or directly within the cytoplasm of the host cells, which can negatively interfere with PTI and ETI. As a result, plants are not able to defend themselves anymore and fall into the state of Effector-Triggered Susceptibility (ETS) [26,32].

Once activated, both PTI and ETI induce a downstream of similar defenses, such as rapid accumulation of reactive oxygen species (ROS), changes in cellular ion fluxes, activation of protein kinase cascades, production of stress-related hormones, cell wall modifications and changes in protein and gene expression $[26,28,34]$. These responses seem stronger and more prolonged during ETI when compared to PTI. ETI is typically associated with the hypersensitive reaction (HR), a form of programmed plant cell death localized at the infection sites [26,35]. HR is considered to be one of the most important factors in the restriction of the pathogen growth, particularly of obligate biotrophs [36,37] such as rust fungi, being responsible for race-specific resistance [38]. Despite their differences and particular features, the two-layered defenses (PTI and ETI) should be considered as a continuum resulting in the activation of an overlapping set of immune reactions [39].

Plants can also induce defense reactions to a broad range of pathogens due to prior exposure to pathogens or physical stress. This ability of plants to react to an invader by triggering local and systemic defense responses is known as systemic acquired resistance (SAR) [40]. It is considered one of the players in a multifaceted inducible defense system in plants, characterized by various signaling pathways and metabolic responses [41-43].

This review provides an overview of our current knowledge on the coffee- $H$. vastatrix interaction, mainly regarding pathogen infection and variability, the discovery of pathogen effectors, breeding for disease resistance, and multilayered host defense responses. This review also contains information about the coffee defense responses activated by the application of resistance inducers, nowadays used as a promising approach to integrate crop protection practices [44]. Emphasis is given to significant advances obtained over past decades through gene expression analysis and the application of various omics methodologies. We also discuss the main challenges for future research in this complex biological system.

\section{CLR Causal Agent: Life Cycle and Biotrophic Infection Process}

H. vastatrix (phylum Basidiomycota, class Pucciniomycetes, order Pucciniales) is a hemicyclic fungus producing urediniospores, teliospores and basidiospores, but only the 
dikaryotic urediniospores, which form the asexual part of the cycle, reinfect coffee leaves successively and are responsible for the disease [7]. H. vastatrix, like other rust fungi, is an obligate biotroph, which means that it can only feed, grow and reproduce on its living host(s). It differentiates specialized infection structures called haustoria that have been linked to pathogen nutrient uptake from the host cell. Haustoria also appear to play essential roles in plant-fungus recognition and delivery of secreted effector proteins into the host cytoplasm for the establishment of a successful biotrophic relationship [45-48].

The $H$. vastatrix infection process begins by the adhesion of urediniospores to the lower surface of the coffee leaves followed by its germination and appressoria differentiation over stomata. Adhesion may be regarded as a necessary prerequisite to establish the fungus on the leaf for successful infection [49]. After adhesion of rust urediniospores to the plant surface, the development of infection structures is the result of a sophisticated host surface recognition system. The tip of the dicaryotic germ tube is able to follow topographical features of the plant cuticle and thus increase the probability of encountering a stomatal opening [49]. Esterases seem to be involved in H. vastatrix urediniospores adhesion and appressoria differentiation [50].

The appressorium is the first infection structure from which $H$. vastatrix is able to penetrate the coffee leaf tissues, reaching sequentially the stages of penetration hypha, anchor and haustorial mother cell, which gives rise to a haustorium, that starts by infecting the stomatal subsidiary cells. Fungal growth continues with the formation of more intercellular hyphae, including HMCs and haustoria, in the spongy and palisade parenchyma, and even the upper epidermis. At this stage, it is possible to observe macroscopic chloroses on the leaf's surface. Once the hyphae invade the substomatal cavities, they differentiate to form protosori, and about 3 weeks after the beginning of the infection urediniosporic sori (Figure 1) protrude through the stomata in a bouquet shape $[7,20,51,52]$.

The development of the entire uredinial cycle depends on environmental conditions $[7,18]$. Urediniospore germination requires water and is optimal at about $24^{\circ} \mathrm{C}$; rain is the primary dispersal mechanism for spores. The time from initial infection to the production of a new sorus is shortened in higher temperatures. Thus, drier, cooler climates are not conducive for CLR spread, whereas warmer, humid climates favor an increase of urediospores (sporulation).

\section{Rust Variability}

The first indication of the adaptive capacity of $H$. vastatrix was the loss of resistance of C. liberica observed in Indonesia between 1880 and 1890, which contributed to the subsequent decline of Liberica coffee cultivation in that country [53]. The loss of resistance of Coorg Arabica variety in India alerted the occurrence of pathological shifts that led, from 1918 to 1920, to its replacement by Kent's Arabica variety, which maintained its resistance to rust for several decades [54]. In 1932, Mayne, in India, presented the first experimental evidence of physiological specialization of $H$. vastatrix by differentiating two races using laboratory inoculations: one only virulent to Coorg (race 1) and the other to both Coorg and Kent's (race 2) [55]. Afterwards, Mayne identified another two races with virulence to S.288 and S. 353 Arabica varieties [56].

Following the creation of the Coffee Rusts Research Center (CIFC, Centro de Investigação das Ferrugens do Cafeeiro) in Portugal in 1955, many samples of leaf rust and coffee genotypes were received from different regions of the world, assisting research of coffee resistance. Thanks to this work, the existence of Mayne's races was confirmed at CIFC, and about 55 additional rust races have been discovered until today $[7,11,20,21,56-61]$. These races have been identified according to the virulence or avirulence reactions they induce when inoculated on a set of 27 coffee differentials: clonal lines of 5 C. arabica selections, 16 tetraploid hybrids of $C$. arabica $\times$ Coffea spp., and 6 Coffea spp. selections $[7,11,21,60]$. $H$. vastatrix races are attributed to isolates with distinct and unique combinations of virulence genes as inferred by Flor's gene-to-gene theory and described as sequential Roman numerals in order of detection [19]. The race genotypes comprise virulence genes ranging from $\mathrm{v}_{1}$ to $\mathrm{v}_{9}$ in isolates derived from C. arabica and tetraploid interspecific hybrids, 
whereas those that attack diploid coffee species are not known due to the unavailability of genetic studies in these hosts $[7,11,20]$. The genetic characterization and confirmation of these virulence loci has not been possible so far, mainly because, on one side, no sexual phase in H. vastatrix's life cycle has yet been identified, and on the other side, no direct link between phenotypic diversity and molecular diversity has been found. These limitations, together with the complexity and large size of H. vastatrix's genome [62-64], have impaired further advances on the development of virulence diagnostic markers. Thus, the virulence profile characterization, particularly of isolates infecting Timor hybrid (HDT) derivatives, can only go as far as the available collection of coffee differential genotypes allows, leaving many genotypes incompletely identified $[7,60]$. For a long time, characterization of the population genetic variability in coffee rust was also intricated, as different studies reported different levels from low to high, but consistently no evidence of population structure could be found with respect to race, host or geographical origin [7]. Recent efforts in genomic research on coffee rust changed this paradigm, and for the first time three divergent genetic lineages were found, highly structured according to coffee hosts ( $\mathrm{C} 1$ and $\mathrm{C} 2$, infecting diploid coffee species; and C3, infecting tetraploid coffee species), revealing footprints of introgression [65]. More recently, additional genomic data allowed further discovery of a well-resolved substructuring within the $\mathrm{C} 3$ lineage, which seems to follow a pattern of local adaptation [66]. With the likely increase of genomic resources in a short time, we might expect to improve our knowledge of population variability and virulence evolution and envision the future development of candidate diagnostic markers associated with rust pathotypes. Additionally, the first version of the core proteome of $H$. vastatrix urediniospores performed by nanoLC-MS/MS analysis has been presented [67]. Proteins were functionally annotated as being involved mainly in DNA integration, RNA-dependent DNA biosynthesis, proteolysis, translation, oxidation-reduction process, primary metabolism, nitrogen compound metabolism and macromolecule metabolic processes. The comparative analysis of the proteomes of the three rust races studied showed that $95 \%$ of the identified proteins (1780 out of 1874) were commonly detected among races. The identification of the protein factors $(5 \%)$ that characterize each virulence profile is under analysis.

\section{Mechanisms of Pathogenicity: The Search for H. vastatrix Effectors}

The prediction of fungal effectors involved in plant interactions has been the focus of much attention by the research community working on plant diseases. Effectors are secreted proteins that move from the fungal to the host cells/tissues, where they induce or suppress plant defense responses since they modulate and interfere with the integrated plant immune system (including both PTI and ETI plant defense responses) [68]. Effector identification has the potential to speed up the selection of plant resistance genes and/or the removal of plant susceptibility genes in breeding programs of relevant agronomic varieties $[69,70]$.

Fernandez et al. [71] obtained the first predict $H$. vastatrix's secretome from $C$. arabica infected leaves by RNAseq. Two years later Talhinhas et al. [72], using RNAseq data from $H$. vastatrix in vitro structures (Figure 2), predicted the secretome of the prepenetration fungal structures. All together, these results generated a collection of 516 transcripts from $H$. vastarix that were predicted as putative secreted proteins. Surprisingly, a high number of these proteins were transcribed in prepenetration fungal structures, representing an early building of the pathogen's virulence machine. 


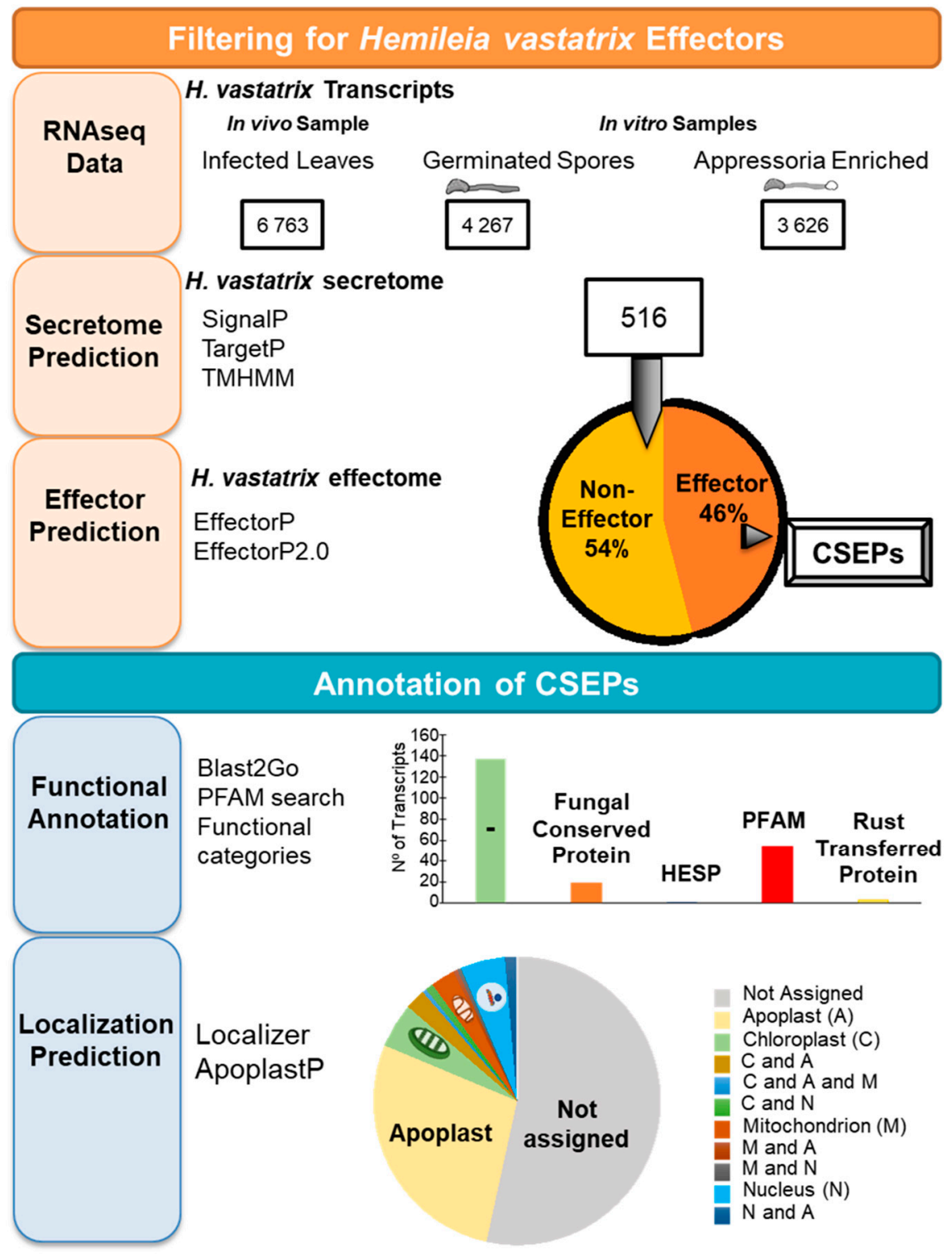

Figure 2. Pipeline for transcriptomic analysis of Hemileia vastatrix key differentiation stages, gene assembly, secretome prediction and bioinformatic annotation.

A machine learning approach was used to predict "Candidate secreted effector proteins" (CSEPs) from H. vastatrix secretome [73,74] (Figure 2). Almost half of the predicted secretome (516 transcripts) were also predicted to be CSEPs. In parallel, in silico annotation, such as the protein families database (Pfam) search, or functional annotation of those CSEPs sequences, revealed that 137 sequences do not contain any conserved protein domain. The activation of genes encoding putative effectors, namely the early activation of RTP (rust transferred proteins) and Gas1-orthologous genes, was observed in susceptible genotypes. Other putative effectors, (e.g., HESP-haustoria expressed secreted protein) seem to be specifically activated in the resistant genotypes and are preferentially expressed after the differentiation of the first haustoria $[75,76]$. The $H$. vastatrix CSEPs predicted subcellular localizations were apoplastic space $(28 \%)$, nucleus $(5 \%)$, chloroplast $(5 \%)$, and mitochondrion (3\%). However, for more than half of the CSEPs no localization was assigned (Figure 2).

The MEME algorithm was used to search for new conserved motifs amongst the sequences obtained by Fernandez et al. [71] and Talhinhas et al. [72]. Four putative secreted proteins were selected [77] (Figure 2) that shared some common features, such as gene organization and amino acid patterns, and their transcript level peaked seven days after inoculation in infected coffee leaves, when haustoria were the predominant fungal 
structure present. Together these results suggest a similar biological function or a common ancestor. The CSEPs were immunolocalized inside of intercellular hyphae and haustoria of $H$. vastatrix in infected leaves. The selected sequences showed the hallmark of true effectors, which needs to be supported by the ongoing effort of identifying the plant proteins interactors. Surprisingly, two CSEPs revealed splicing variants, which had a distinct transcription profile in leaves of Coffea spp. inoculated with different $H$. vastatrix isolates, and a different subcellular localization in leaves of Nicotiana benthamiana agroinfiltrated with the different variants. The splicing variants identified may contribute to increasing the "arsenal" diversity that $H$. vastatrix employs in the "arms race" against Coffea spp. immunity and may contribute to the diversification of $H$. vastatrix virulence potential [77].

The first CSEP from $H$. vastatrix to be identified as a bona fide effector was described in a noteworthy study conducted by Maia et al. [78] that started with the identification of CSEPs using RNAseq data. The novelty presented in this publication lies in the system used to deliver CSEPs into the cytoplasm of coffee leaf cells: the type-three secretion system of Pseudomonas syringae pv. garcae. Once proved that the CSEPs were inside the cells, the authors could determine which CSEPs influenced the growth of P. syringae pv. garcae in selected Coffea genotypes. They observed a suppression of bacterial growth by HVEC016 effector, when inside of leaves from $\mathrm{S}_{\mathrm{H}} 1$ plants; suggesting that this effector can be recognized by a coffee plant with a $\mathrm{S}_{\mathrm{H}} 1$ background. This tool for delivering CSEPs inside leaf cells is of special relevance for further studies, considering the reduced number of molecular tools available for functional characterization in coffee plants.

\section{Disease Resistance Breeding}

Disease resistance is often the most dynamic component of the crop breeding process, requiring continual updating due to pathogen adaptation to plant genotypes [79]. It is challenging to breed varieties with resistance that is effective, stable and broad-spectrum.

Plant disease resistance can be categorised in several concepts that are related to different aspects, including the genetic background of the resistance (monogenic/polygenic), the effect of the measurable phenotypic response (complete/partial resistance) and the effective broad-range or species-specific nature of resistance against pathogens (race-specific and race nonspecific resistance) [39].

For many years, selection for $H$. vastatrix resistance has been based on highly specific complete resistance derived from major introgressed genes derived from C. arabica $\left(\mathrm{S}_{\mathrm{H}} 1\right.$, $\mathrm{S}_{\mathrm{H}} 2, \mathrm{~S}_{\mathrm{H}} 4$ and $\left.\mathrm{S}_{\mathrm{H}} 5\right)$, as well as diploid species such as C. canephora $\left(\mathrm{S}_{\mathrm{H}} 6-\mathrm{S}_{\mathrm{H}} 9\right)$ or C. liberica $\left(S_{H^{3}}\right)[11,19,20]$. However, the pathogen's high degree of variability and adaptability, together with the consequent occurrence of frequent shifts in pathotypes, has resulted in the gradual loss of the resistance based on major $S_{H}$ genes. Partial and non-specific polygenic resistance to $H$. vastatrix had been identified in C. canephora, in some C. arabica genotypes and interspecific hybrids [52,80,81] and had been associated with the slow epidemic progress and less defoliation [82]. Thus, coffee breeding programs are trying to develop strategies to improve the durability of CLR resistance in Arabica cultivars, namely through the combination of specific (complete) and nonspecific (partial) resistance [80,83].

Molecular marker-assisted selection (MAS) offers the chance to speed up individual resistance screening and increase breeding efficiency, allowing gene stacking into a single line with a high degree of parental genome recovery. In fact, current developments in plant breeding are moving towards combining different forms of resistance simultaneously by pyramiding various genes that cover a diverse range of resistance mechanisms. As promising as these strategies are for durable broad-spectrum resistance, they require the tagging of resistance genes by tightly linked markers, and ultimately their molecular characterization, which can be a hard task when dealing with highly complex polygenic traits in polyploid species. To date, the $\mathrm{S}_{\mathrm{H}} 3$ locus derived from $\mathrm{C}$. liberica has been the only rust-resistance gene genetically and physically characterized in coffee [84], corresponding to a complex multi-gene cluster which includes at least three R-genes (i.e., CC-NBS-LRR type) [85]. Despite these constraints, over the last seventeen years a few studies have 
successfully developed markers closely linked to some $H$. vastatrix resistance genes in C. arabica and HDT-derivatives. Prakash et al. [86] and Mahé et al. [87] developed the first locus-specific markers cosegregating with $\mathrm{S}_{\mathrm{H}} 3$ derived from introgression into C. arabica. Herrera et al. [80] followed by identifying AFLP and SSR markers associated with partial rust resistance in an HDT-derived population, and later Romero et al. [88], analyzing the same population, mapped a quantitative trait locus (QTL) associated with a new SH factor only present in genotypes derived from CIFC 1343 and H832/2 accessions. Using an F2 population of an HDT-derived line, de Brito et al. [89] identified a genomic region involved in resistance to race II, suggesting it corresponds with one of the $\mathrm{S}_{\mathrm{H}}$ genes $\left(\mathrm{S}_{\mathrm{H}} 7-\mathrm{S}_{\mathrm{H}} 9\right)$ present in HDT or another unknown gene, for which Diola et al. [90] developed SCAR markers flanking it. More recently, resistance to three different $H$. vastatrix pathotypes in another HDT-derived lineage was shown to be conferred by at least two independent dominant QTLs [91]. These genetic resources opened new possibilities for MAS-driven resistance breeding in coffee, prompting the first reports of successful marker validation and selection of coffee cultivars harboring distinct loci for resistance, not only to CLR, but also to coffee berry disease (CBD) [92,93]. Other promising genomic-driven approaches to improve coffee breeding for durable and broad-spectrum resistance have been studied, such as genomic selection [94], and genomics-assisted exploitation of mutant or impaired susceptibility (S)-genes in the host plant that will lead to "loss of susceptibility" [95].

\subsection{Sources of Resistance to CLR}

Coffee breeding for CLR resistance emerged at the turn of the 20th century through the work of enterprising growers aiming to obtain Arabica cultivars with improved resistance to H. vastatrix. The first such breeding endeavor was conducted in 1901, in Indonesia, with materials derived from several spontaneous interspecific hybrids between $C$. arabica and C. liberica, but without success, and soon the work was abandoned [53]. Afterwards, the first results of early selection efforts to obtain Arabica host resistance to CLR were reported in India around the 1920s, and although having a long history of initial successes, they were followed by disappointments, namely of the folk selections "Coorgs" and "Kents", which quickly fell susceptible to the disease [54].

Between 1925 and 1926 the Experimental Station of Balehonnur, in India, started a genetic breeding Arabica program for resistance to $H$. vastatrix based on interspecific hybrids resulting from crosses carried out by regional coffee growers between plants of the local variety of $C$ arabica and plants of $C$. liberica species. The earliest of such hybrids involved in Arabica breeding was S.26 carrying the $\mathrm{S}_{\mathrm{H}} 3$ gene, which was introduced in the development of the Indian coffee selections S.288 and S.795 and released for commercial cultivation in late 1930s. These coffee selections, which initially showed resistance to $H$. vastatrix in the field, began, after some years of cultivation in India, to be affected, though without great severity $[96,97]$. From 1952 onwards, several sources of resistance in C. arabica were identified and classified in CIFC into eight physiological resistance groups $(C, \alpha, D, J, Y, I, W$ and $L)$ in coffee trees originating from Ethiopia and Sudan, some of which received designations known today such as Dilla \& Alghe, Geisha, Barbuck Sudan, BE-5 Wush Wush, S4 Agaro, S.6 Cioiccie, S.12 Kaffa and S.16 Wollamo. However, none of these coffee trees showed resistance to all known rust races $[11,20]$.

Contrary to what was seen with C. arabica, it was quite easy to find plants with high resistance to the races of $H$. vastatrix within diploid species such as $C$. canephora, $C$. congensis, C. dewevrei and C. liberica, and others [98]. In an attempt to introduce such resistance into C. arabica, researchers of Brazil and Ivory Coast developed tetraploid C. canephora trees with resistance to $H$. vastatrix through colchicine duplication of the chromosome number of the coffee plants, which in turn were hybridized with traditional cultivars of $C$. arabica, giving rise to the Icatú varieties in Brazil in 1950 and Arabusta in Ivory Coast in 1960 [11,99-101] 


\subsubsection{Spontaneous Interspecific Hybrids}

The occurrence and discovery of spontaneous interspecific coffee hybrids over the last two centuries has provided important sources of rust resistance. From 1886 onwards, numerous spontaneous hybrids showing resistance to $H$. vastatrix were found in various coffee-growing regions, such as the hybrids of $C$. arabica $\times$ C. liberica designated as "Kallimas", "Bandjar Sari" and "Kawisari B and D" in Indonesia [53]. In the early 50's, the hybrid Devamachy (C. arabica $\times$ C. canephora) was found in India, being still commercially exploited as "Selection-5" [102], while the most recent evidence for spontaneous hybridization of C. arabica and C. canephora has come from New Caledonia [103]. Nonetheless the contribution of these hybrids for improving coffee resistance, the greatest discovery to date of a natural hybrid widely impacting on coffee production, was that of the HDT, which led to a turning point in coffee breeding history.

\subsubsection{Timor Hybrid (HDT)}

In 1927, in a plantation of the Arabica's variety Typica on the Timor island (East Timor was a Portuguese colony), a coffee tree showing no disease symptoms within a highly rust affected field was discovered, resulting from a natural cross between C. arabica and C. canephora [104-106]. Seeds from this plant were used to establish small coffee plantations, giving rise to a population, commonly known as "Timor hybrid", which presented a phenotype similar to Arabica and a marked resistance to H. vastatrix. Seeds from the best plants of this population were used from 1956 onwards for the formation, on a large scale, of new coffee plantations throughout the island. Following this expansion, in the 1960s, about $60 \%$ of the coffee cultivated in Timor-Leste was Arabica, of which $80 \%$ consisted of the CLR-resistant HDT variety $[104,107]$. Within its mission of supporting coffee breeding worldwide, CIFC received numerous HDT samples from East Timor, from which the most used as sources of resistance in breeding programs, as well as in genetic studies, are: CIFC HDT 832 (received 1957); CIFC HDT 1343 (received 1960); CIFC HDT 2570 (received 1968) and the clone CIFC HDT 4106 (1971) from the supposed original hybrid of Timor [60]. From the studies, one of the major breakthroughs for the Arabica coffee breeding programs was the discovery of the resistance factors of HDT, as well as the possibility to transfer these characteristics to the traditional commercial varieties $[7,11]$. Based on those HDT resources, during the second half of the 20th century comprehensive breeding programs applying Mendelian and quantitative genetics, plant pathology, crop physiology and agronomy, were implemented by research centers in several coffee growing countries: India (CCRI), Brazil (IAC, IAPAR, UFV-EPAMIG, PROCAFÉ/MAPA), Colombia (CENICAFE), Costa Rica (CATIE/PROMECAFE/CIRAD), Kenya (CRF), Tanzania (TaCRI) and Angola/Portugal (IAA/ICA-CIFC/ex IICT) $[6,100,108]$.

\subsubsection{HDT Germplasm}

From the originally received HDT genotypes channeled by CIFC for several countries, an explosive production of rust resistant germplasm followed in the scope of local Arabica breeding programs. For instance, HDT 832/1 was the progenitor for development of varieties such as Sabiá, Palma, Oeiras, Canário and Liberdade in Brazil; Anacafe 14, Catisic, Fronton, Oro Azteca Catimor, Costa Rica 95, Ihcafe 90, Lempira in Central America and Cauvery in India [100,109-111]. HDT 832/2, on the other hand, was the progenitor for the development of varieties Acauã, Tupi, Obatã, Iapar 59, IPR 98, IPR 99, IPR 104, Arara, Asa Branca in Brasil [109,110,112] and Chandragiri in India [113], Cuscatleco, Limani, Marsellesa, Parainema, Milenio as well as F1 Hybrids Starmaya and Mundo Maya (T5296 $\times$ wild Ethiopian accessions) in Central America [111,114,115]. Using a multilineal strategy of compound varieties, CIFC HDT 1343 was extensively used in Colombia to produce, among others, Colombia, Tabi, Castillo and Cenicafé 1 [116-118]. CIFC HDT 1343 was also used in Kenya to develop the varieties Ruiru 11 and Batian, as well as cultivar Catimor 129 grown in several African growing countries such as Malawi and 
Zimbabwe [111,119,120]. Finally, the introduction in Brazil of CIFC HDT 2570 gave origin to the varieties Araponga, Paraíso, Catiguá and Pau Brasil [110,121].

CIFC had also a major role in selecting from HDT populations genotypes with different levels of resistance to $H$. vastatrix, and the majority were sent to research institutions in different coffee regions in the world. In some of these regions, such as Brazil, some populations descending from HDT received widely referenced designations such as Catimor and Sarchimor [11,100,122]. The populations derived from the hybrids CIFC HW $26(19 / 1$ Red Caturra $\times$ HDT 832/1) and CIFC HW 46 (19/1 Red Caturra $\times$ HDT 832/2) received at UFV the designation of Catimor, resulting from the contraction of the words Caturra and HDT [123]. Later, the same designation of Catimor came to be used in several different contexts, such as derivatives of the Hybrid" Yellow Catuaí CCC $135 \times$ HDT 1343" produced by CENICAFÉ in Colombia. Since the 1980s, the name Catimor has been indiscriminately used by researchers, breeders, and roasters to designate varieties, cultivars, introductions, "accessions" and different genotypes derived from hybrids between Arabica (Caturra and Catuaí) and any HDT introduction. On the other hand, populations originated from the hybrid CIFC H 361 (Villa Sarchi CIFC 971/10 × CIFC 832/2) received the designation of Sarchimor, analogous with the name Catimor. Other designations have been attributed following the same rationale. The cross between Yellow Caturra CIFC 1637 and CIFC $\mathrm{H} 361$ / 4 gave rise to the hybrid CIFC H529, which in Brazil received the designation UFV 351 and originated the genetic material that later came to be generically designated as Cachimor [124-126].

In recent years, in some coffee-growing countries, some resistant varieties have shown susceptibility to rust $[7,60,112]$. The same happened to the original sources of resistance HDT 832/1, HDT 832/2 and the clone of the supposed original HDT hybrid, CIFC 4016, that showed susceptibility to rust samples from some coffee growing regions under greenhouse conditions at CIFC [60]. However, in many countries, although some resistant varieties started to show some susceptibility, they are still preferred for their agronomic characteristics when compared to traditional varieties once the basic condition of productivity of these coffee trees persists $[60,112,127]$.

Many HDT derivatives offer resistance, not only to coffee leaf rust, but also to root-knot nematodes (Meloidogyne spp.), coffee berry disease (Colletotrichum kahawae), bacterial blight of coffee (Pseudomonas syringae pv. garcae) and possibly other pathogens [119,121,128-133].

\section{Coffee Defense Mechanisms}

Significant advances have been made in the knowledge of the resistance mechanisms induced by the pathogen at the cytological and biochemical levels and, more recently, through analytical chemistry, gene expression analysis and the application of various omics approaches (as summarized in Tables 1-3). Nevertheless, the existence of constitutive barriers in coffee that could prevent $H$. vastatrix infection has not been disclosed so far $[52,134,135]$. Cytological studies revealed that once $H$. vastatrix urediniospores germinate, germ tubes generally have a similar level of success in finding stomata and forming appressoria in resistant and susceptible coffee leaves [52,136]. However, in resistant plants, fungal growth is typically arrested in any of the sequential stages of appressorium, penetration hypha, anchor or haustorial mother cell, with or without haustorium. Therefore, two types of resistance can be characterized: (i) pre-haustorial resistance, when the fungal growth stopped before haustorium formation in the majority of the infection sites; (ii) posthaustorial resistance, when the fungus growth stopped more frequently after forming at least one haustorium [52,136-142]. Both types of resistance are associated with the HR, although this response is displayed earlier in the pre-haustorial than in the post-haustorial resistance. HR is first observed in the guard cells only, or in both the guard and subsidiary stomatal cells, at infection sites in which the fungus ceased its growth in the stage of appressorium or in the subsequent pre-haustorial structures. HR of subsidiary and mesophyll cells invaded by haustoria is observed later and, during the time course of infection, cell death spreads to adjacent noninvaded cells [52,136,137,140-142]. 
Table 1. Coffee defense responses induced by Hemileia vastatrix, based on different research fields: cytology, analytical chemistry, and biochemistry.

\begin{tabular}{|c|c|c|}
\hline Research Fields & Coffee Defense Responses & References \\
\hline \multirow{7}{*}{ Cytology } & $\begin{array}{l}\text { ROS accumulation in the cell walls and } \\
\text { cytoplasmic contents }\end{array}$ & {$[136,143,144]$} \\
\hline & Deployment of hypersensitive response (HR) & {$[52,136,137,140-142]$} \\
\hline & $\begin{array}{l}\text { Accumulation of phenolic-like compounds } \\
\text { (Cell walls and cytoplasmic contents) }\end{array}$ & {$[52,136,137,140]$} \\
\hline & Lignification of cell walls & {$[52,137]$} \\
\hline & $\begin{array}{l}\text { Haustorium encasement with callose } \\
\text { and } \beta-1,4 \text {-glucans }\end{array}$ & {$[52,137]$} \\
\hline & Cell hypertrophy & {$[20,52,137]$} \\
\hline & $\begin{array}{l}\text { Accumulation of a material partially } \\
\text { crystallised (containing pectins, } \\
\text { polysaccharides and phenolic-like } \\
\text { compounds) in the intercellular spaces }\end{array}$ & {$[52,137]$} \\
\hline \multirow{2}{*}{ Analytical chemistry } & Increase in salicylic acid (SA) levels & [145] \\
\hline & $\begin{array}{l}\text { Increase of chlorogenic acids } \\
(4,5 \text {-diCQA) content }\end{array}$ & [146] \\
\hline \multirow{6}{*}{ Biochemistry } & Increase in chitinases and glucanases activity & {$[147,148]$} \\
\hline & Immunodetection of class I chitinases & [147] \\
\hline & Increase in peroxidase (POD) activity & [136] \\
\hline & $\begin{array}{l}\text { Increase in superoxide dismutase } \\
\text { (SOD) activity }\end{array}$ & [139] \\
\hline & Increase in lipoxygenase (LOX) activity & [149] \\
\hline & $\begin{array}{l}\text { Increase in phenylalanine ammonia lyase } \\
\text { (PAL) activity }\end{array}$ & [137] \\
\hline
\end{tabular}

Table 2. Genes putatively involved in coffee resistance to Hemileia vastatrix based on RT-qPCR analysis.

\begin{tabular}{|c|c|c|c|}
\hline Gene & Annotation & Accession Number & Reference \\
\hline CaRLK & Receptor-like kinase & DSS6; CF589181 & {$[140,150]$} \\
\hline NB-ARC domain & $\begin{array}{l}\text { NB-ARC domain-containing disease } \\
\text { resistance protein }\end{array}$ & n.a. & [151] \\
\hline SD1-8 & $\begin{array}{l}\text { Receptor-like } \\
\text { serine/threonine-protein } \\
\text { kinase SD1-8 }\end{array}$ & n.a. & [151] \\
\hline NBS-LRR & $\begin{array}{l}\text { Nucleotide-binding } \\
\text { site-leucine-rich repeat }\end{array}$ & DQ123968; GT030058.1 & {$[152,153]$} \\
\hline At5g39020 & $\begin{array}{l}\text { Putative probable receptor-like } \\
\text { protein kinase At5g39020 }\end{array}$ & n.a. & [151] \\
\hline LRR_RLK2 & $\begin{array}{l}\text { Leucine-rich repeat receptor-like } \\
\text { protein kinase }\end{array}$ & Contig_37_g342.t1 & [22] \\
\hline RGH1A & Resistance gene analogs 1A & GT029983.1 & [152] \\
\hline NDR1 & $\begin{array}{l}\text { Non-race specific Disease } \\
\text { Resistance } 1\end{array}$ & DSS12; CO773976 & {$[138,150,154]$} \\
\hline CDPK5 & Calcium-dependent protein kinase 5 & GT030068.1 & [152] \\
\hline CBP & Calmodulin-binding protein & GT030070.1 & [152] \\
\hline CaWRKY1 & WRKY transcription factor 1 & DSS16 & {$[138,140,150,155,156]$} \\
\hline CaWRKY1a & WRKY transcription factor $1 a$ & n.a. & {$[156,157]$} \\
\hline CaWRKY1b & WRKY transcription factor $1 b$ & n.a. & {$[156,157]$} \\
\hline
\end{tabular}


Table 2. Cont.

\begin{tabular}{|c|c|c|c|}
\hline Gene & Annotation & Accession Number & Reference \\
\hline CaWRKY3 & WRKY transcription factor 3 & $\begin{array}{l}\text { GT715378; GT715379; GT669686; } \\
\text { GT684003; GT675420; GT675421; } \\
\text { GT675422; GT675423 }\end{array}$ & [155] \\
\hline CaWRKY6 & WRKY transcription factor 6 & $\begin{array}{l}\text { GW460548; GW439927; GT671542; } \\
\text { GT700942; GT688469; GT722306 }\end{array}$ & [155] \\
\hline CaWRKY7 & WRKY transcription factor 7 & n.a. & [155] \\
\hline CaWRKY8 & WRKY transcription factor 8 & GT685360; GW436389 & [155] \\
\hline CaWRKY10 & WRKY transcription factor 10 & DV693086 & [155] \\
\hline CaWRKY11 & WRKY transcription factor 11 & $\begin{array}{l}\text { GW489409; GW472658; GW489686; } \\
\text { GW467855 }\end{array}$ & [155] \\
\hline CaWRKY12 & WRKY transcription factor 12 & GW487300; GT715908 & [155] \\
\hline CaWRKY13 & WRKY transcription factor 13 & GW428837; GW469454 & [155] \\
\hline CaWRKY14 & WRKY transcription factor 14 & $\begin{array}{l}\text { GT730216; GT688262; GT688263; } \\
\text { GT733537 }\end{array}$ & [155] \\
\hline CaWRKY15 & WRKY transcription factor 15 & $\begin{array}{l}\text { GT725660; GT721476; GT721477; } \\
\text { GT704531; GT707389; GT702040; } \\
\text { GT702041; GW490838; GT695761; } \\
\text { GT674787; GT704614 }\end{array}$ & [155] \\
\hline CaWRKY17 & WRKY transcription factor 17 & DV678740 & [155] \\
\hline CaWRKY19 & WRKY transcription factor 19 & $\begin{array}{l}\text { GW490173; GW439047; GW438774; } \\
\text { GW472647; GW481654 }\end{array}$ & [155] \\
\hline CaWRKY20 & WRKY transcription factor 20 & DV706804 & {$[155]$} \\
\hline CaWRKY21 & WRKY transcription factor 21 & DV709595.1 & [155] \\
\hline CaWRKY22 & WRKY transcription factor 22 & GT685546; GT684702 & [155] \\
\hline bHLH & $\begin{array}{l}\text { Putative basic helix-loop-helix } \\
\text { (bHLH) DNA-binding } \\
\text { superfamily protein }\end{array}$ & n.a. & [151] \\
\hline $\begin{array}{l}\text { AP2-type transcription } \\
\text { factor }\end{array}$ & AP2-type transcription factor & DSS17 & [150] \\
\hline bZIP56 & Transcription factor bZIP56 & GT030080.1 & [152] \\
\hline MAPK2 & Mitogen-activated protein kinase 2 & GT030062.1 & [152] \\
\hline MEK2 & $\begin{array}{l}\text { Dual specificity mitogen-activated } \\
\text { protein kinase kinase } 2\end{array}$ & GT030000.1 & [152] \\
\hline 13-LOX & Lipoxygenase 13 & DV704189 & {$[140,142]$} \\
\hline LOX & Lipoxygenase & DQ123948 & {$[153]$} \\
\hline CaPAL & Phenylalanine ammonia lyase & DQ067599; JF838179 & [140] \\
\hline NPR1 & $\begin{array}{l}\text { Non-expressor of } \\
\text { pathogenesis-related gene }\end{array}$ & n.a. & [154] \\
\hline CaGT & Salicylic acid-glucosyltransferase & DSS22; CO773975 & {$[140,150]$} \\
\hline ERF & $\begin{array}{l}\text { Ethylene-responsive transcription } \\
\text { factor } 1 \mathrm{~B}\end{array}$ & n.a. & [151] \\
\hline $\mathrm{ABC}$ & PDR-type ABC transporter 1 & DQ123937 & {$[153]$} \\
\hline PR1 & Pathogenesis-related protein 1 & n.a. & {$[154]$} \\
\hline
\end{tabular}


Table 2. Cont.

\begin{tabular}{|c|c|c|c|}
\hline Gene & Annotation & Accession Number & Reference \\
\hline CaPR1b & Pathogenesis-related protein $1 \mathrm{~b}$ & DQ335594 & {$[140,142,143]$} \\
\hline PR2 & $\begin{array}{l}\text { Pathogenesis-related protein } 2 \\
\text { (beta-1,3-glucanase) }\end{array}$ & DQ123927 & [153] \\
\hline PR5 & $\begin{array}{l}\text { Pathogen-related protein } 5 \\
\text { (thaumatin-like gene) }\end{array}$ & GT030025.1 & [152] \\
\hline CaPR10 & Pathogenesis-related protein 10 & CF589103 & {$[140,143]$} \\
\hline PNC2 & Cationic peroxidase 2 & n.a. & [151] \\
\hline R1A-6 & $\begin{array}{l}\text { Putative late blight resistance protein } \\
\text { homolog R1A-6 }\end{array}$ & n.a. & [151] \\
\hline RGA1 & $\begin{array}{l}\text { Putative disease resistance } \\
\text { protein RGA1 }\end{array}$ & n.a. & [151] \\
\hline PUB24 & $\begin{array}{l}\text { Putative E3 ubiquitin-protein } \\
\text { ligase PUB24 }\end{array}$ & n.a. & [151] \\
\hline ITN1 & $\begin{array}{l}\text { Putative ankyrin repeat-containing } \\
\text { protein At3g12360 }\end{array}$ & n.a. & [151] \\
\hline Dirigent-like protein & $\begin{array}{l}\text { Putative disease resistance-responsive } \\
\text { (dirigent- like protein) family protein }\end{array}$ & n.a. & [151] \\
\hline $\begin{array}{l}\text { Premnaspiridione } \\
\text { oxygenase }\end{array}$ & Premnaspiridione oxygenase & n.a. & [151] \\
\hline CyP450 & Cytochrome P450 & DSS10 & [150] \\
\hline HSP70 & 70-kDa heat shock proteins & $\begin{array}{l}\text { DSS11; DSS16; CO773974; } \\
\text { DQ335599 }\end{array}$ & [150] \\
\hline CaR111 & Unknown function & DSS23; CF589193 & {$[138,150]$} \\
\hline
\end{tabular}

Table 3. Coffee leaf apoplastic proteins that increase in abundance in the resistant plants at 1, 2, 3 and 4 days after inoculation (d.a.i.) with H. vastatrix (based on [141]).

\begin{tabular}{|c|c|c|c|c|}
\hline d.a.i & Protein Identity $^{a}$ & Superfamily ${ }^{b}$ & Functional Annotation ${ }^{c}$ & $\begin{array}{l}\text { Number } \\
\text { of Spots }\end{array}$ \\
\hline \multirow{7}{*}{1} & Calcineurin-like phosphoesterase & Metallophosphatases & Miscellaneous enzymes & 1 \\
\hline & Cysteine proteinase aleuran type & Peptidase_C1 & Protein degradation & 1 \\
\hline & Subtilisin-like protease & Peptidases_S8_S54 & Protein degradation & 2 \\
\hline & Berberine bridge enzyme & FAD_binding & Secondary metabolism & 1 \\
\hline & Osmotin & GH64-Thaumatin-like & Stress/Defense & 1 \\
\hline & Cysteine-rich repeat secretory protein 55-like & Stress-antifungal & Stress/Defense & 1 \\
\hline & Chitinase-like protein & GH18_chitinase-like & Stress/Defense & 1 \\
\hline \multirow[t]{5}{*}{2} & Chitinase-like protein & GH18_chitinase-like & Stress/Defense & 2 \\
\hline & Beta-xylosidase/alpha-L-Arabinofuranosidase & GH3 & Cell wall degradation & 7 \\
\hline & Pectin methylesterase & Pectinesterase & Cell wall & 1 \\
\hline & Pectinesterase-like & Pectinesterase & Cell wall & 1 \\
\hline & purple acid phosphatase & Metallophosphatases & Miscellaneous enzymes & 1 \\
\hline \multirow[t]{5}{*}{3} & Aspartic proteinase nepenthesin-1-like & pepsin_retropepsin & Protein degradation & 2 \\
\hline & Serine carboxypeptidase & Peptidase_S10 & Protein degradation & 4 \\
\hline & Subtilisin-like protease & Peptidases_S8_S53 & Protein degradation & 6 \\
\hline & Chitinase-like protein & GH18_chitinase-like & Stress/Defense & 1 \\
\hline & Pathogenesis-related protein 5-like & GH64-Thaumatin-like & Stress/Defense & 1 \\
\hline
\end{tabular}


Table 3. Cont.

\begin{tabular}{|c|c|c|c|c|}
\hline d.a.i & Protein Identity $^{a}$ & Superfamily ${ }^{b}$ & Functional Annotation ${ }^{c}$ & $\begin{array}{l}\text { Number } \\
\text { of Spots }\end{array}$ \\
\hline \multirow{7}{*}{4} & Beta-xylosidase/alpha-L-Arabinofuranosidase & $\mathrm{GH} 3$ & Cell wall degradation & 1 \\
\hline & Alpha-L-fucosidase & Alpha-amylase & Cell wall degradation & 2 \\
\hline & Non-cell-autonomous protein pathway & Aldose_epim & Minor CHO metabolism & 1 \\
\hline & Lysosomal alpha-mannosidase-like & $\mathrm{GH} 38$ & Miscellaneous enzymes & 2 \\
\hline & Alpha-xylosidase 1 & GH31 & Miscellaneous enzymes & 1 \\
\hline & ASPARTIC PROTEASE IN GUARD CELL-like protein & pepsin_retropepsin & Protein degradation & 2 \\
\hline & Germin-like protein & Cupin & Stress/Defense & 1 \\
\hline
\end{tabular}

a The peptides separated by 2-DE were identified by matrix assisted laser desorption/ionization time of flightmass spectrometry (MALDI-TOF/TOF MS) followed by homology search on NCBI Viridiplantae and ESTcoffee databases; ${ }^{b}$ Superfamily according to NCBI classification. GH_Glycoside Hydrolase; FAD_binding-flavodoxin binding oxidoreductase; ' Functional annotation based on MapMan 'Bin' and Go ontology.

In susceptible coffee genotypes, fungal colonization results in sporulation. Nevertheless, there is a variable proportion of germinated urediniospores that fail to form haustoria and are associated with HR [136,137,141,142], suggesting the existence of basal resistance. Thus, in both compatible and incompatible coffee- $H$. vastatrix interactions it seems that the contact between the fungus and the host cells triggers PAMP induced responses and is sufficient to induce HR of stomatal cells. In the incompatible interactions, the HR of host cells invaded by haustoria can be attributed to ETI, as well as other host responses, that result in the arrest of fungal growth.

HR has been monitored by autofluorescence and/or browning of the cytoplasmic contents or by its deep blue staining with Evans's blue [52,136,137,140-142]. Ultrastructural modifications of coffee leaf cells undergoing HR reveal breakdown of membranes, change in the appearance of chloroplasts and the nucleus, and coagulation of the cytoplasm [136,137].

Most of the $C$. arabica-H. vastatrix incompatible interactions have been characterized as post-haustorial resistance [52,136,137,141,147]. Resistance-donor genotypes, such as the Kawisari hybrid $(C$. arabica $\times$ C. liberica), used in breeding programs in India, also have post-haustorial defense mechanisms [142], unlike some HDT derivatives used worldwide [60,140,151]. Particularly, HDT832/2 displayed similar pre-haustorial mechanisms in host resistance to $H$. vastatrix and nonhost resistance to Uromyces vignae, as revealed by light microscopy, RT-qPCR gene expression analysis [140] and 454 pyrosequencing [60], which may explain the longer durability of resistance found in this coffee genotype. Indeed, according to Niks et al. [158] and Vaz-Patto et al. [159], mechanisms of rust resistance acting before the haustoria formation, which are very common in nonhost interactions, is hard to overcome by the pathogen, and therefore is of practical interest for breeding.

Almost twenty years have passed since the first identification of Coffea spp. genes involved in the defense response to H. vastatrix [150]. Fast-forward to the present day, methodologies such as cDNA_AFLP sequencing [152], and several transcriptomic approaches as suppression subtractive hybridization (SSH) [150,153,160], 454 pyrosequencing [161], and high throughput RNA sequencing by Illumina [151] have been used to increase understanding of the coffee resistance mechanisms. These methodologies have allowed the identification of genes putatively involved in coffee resistance to Hemileia vastatrix, namely genes related to pathogen recognition, signaling, transcription, defense, oxidative burst, hypersensitive response, phytohormones pathways, synthesis and transport of antimicrobial proteins/metabolites, secondary metabolites biosynthesis, and callose deposition (Table S1).

Plant perception of the pathogen invasion follows a surveillance system assembled in a multilayer fashion to identify apoplastic and cytoplasmatic pathogen effectors. At the early stages of the infection process, some of the multi-domain recognition receptors are activated in the incompatible coffee- $H$. vastatrix interaction ( $R L K$ and $L R R-R L K 2, N B S-L R R$ ), suggesting their role in the host resistance response [22,140,150,152,153]. Nevertheless, in some other incompatible coffee- $H$. vastatrix interactions, this may not be the case $[143,152]$, 
indicating that immune receptors can have different mechanisms for ligand binding and receptor complex formation, which can modulate the activation, intensity and duration of plant immune responses [162]. Non-race specific disease resistance 1 (NDR1), an important activation element of PTI and ETI defense barriers, is required to rapidly activate and amplify the initial events following pathogen perception [163]. CaNDR1 encodes for a plasma membrane-resident protein with a similar structure to the NDR1/HIN1-like (NHL) protein superfamily of plant defense-associated proteins [164]. In different C. arabica genotypes, NDR1 was found to be significantly up-regulated during HR [138,150,154], and its functional characterization in coffee plants predicts a similar mechanistic conservation as observed in Arabidopsis [164,165].

A rapid increase in cytoplasmic calcium concentration is one of the earliest defense responses in PAMP-induced immunity. $\mathrm{Ca}^{2+}$ is one of the most prominent secondary messengers, and its spatial distribution in the cell is controlled by a complex network of calcium sensors and channels that operates at the plasma membrane, cytosol and organelles, including the nucleus [166]. $\mathrm{Ca}^{2+}$ binds to a plethora of sensors such as, calmodulin (CaM), CaM-like proteins (CML), and calcium-dependent protein kinases (CDPK) that activate target proteins either by direct binding or through phosphorylation (P) [167]. Two calciumrelated genes (Calcium-dependent protein kinase 5-CDPK5, and Calmodulin-binding protein-CaMBP) have been studied and related to coffee resistance to rust [152]. The accumulation of calcineurin-like phosphoesterase (a calcium-dependent phosphatase) in the apoplast of resistant coffee leaves, was shown by proteomic analysis [141], emphasizing the importance of this molecule (together with phosphatases) in signal transduction and rapid defense response.

In addition to RLK and CDPK, mitogen-activated protein kinase (MAPK) is also involved to coffee resistance to $H$. vastatrix. MAPKs cascades play an essential role in transduction of environmental and developmental signals [168]. MAPKs are located in the cytoplasm or nucleus, and kinase cascades are activated by PAMPs or pathogen effectors [168,169]. The number of MAPKs involved in coffee resistance to $H$. vastatrix are still unknown. Diola et al. [152] identified three MAPKs, and only two (MAPK2 and MEK2) were up-regulated in resistant Coffea spp. genotypes to $H$. vastatrix race II, suggesting that they are important signaling elements of the defense response.

One of the largest families of transcriptional regulators found exclusively in plants are the WRKY's. They were described as playing critical roles in repressing or activating plant defense responses through direct or indirect interaction with PAMPs, effector proteins or being regulated by MAPK [170,171]. According to Ramiro et al. [155] 22 unigenes encoding WRKYS transcription factors were identified in coffee. From these, $78 \%$ were activated in resistance responses to $H$. vastatrix. A first group of genes which included CaWRKY6, CaWRKY11, CaWRKY12, CaWRKY13/14 and CaWRKY15 was moderately activated while another set, CaWRKY1, CCWRKY17, CaWRKY19/20/21, was strongly and transiently activated during the time course of infection [150,155-157]. In coffee-H. vastatrix interactions, CaWRKY1 (CaWRKY1a and CaWRKY1b) is one of the most studied WRKY genes and seems to be engaged in coffee resistance to $H$. vastatrix. Its early activation pattern is coincident with pathogen entry into the plant and deployment of HR [138,140,156,157]. Other transcription factors such as Ap2 (AP2 type transcription factor) [150], bHLH (basic helixloop-helix DNA- binding protein) [151] and bZIP56 (bZIP transcription factor) [152] may also be involved in the regulation of resistance responses/defense mechanisms of coffee. These genes were found to be up-regulated in the several coffee- $H$. vastatrix incompatible interactions studied [150-152].

Phytohormones can regulate plant growth, developmental processes, and disease resistance. Among them, jasmonic acid (JA), salicylic acid (SA), and ethylene (ET) are classically related to plant defense acting interdependently through complex antagonistic or synergistic interactions [172]. Until now, the role and modulation of JA, SA and ET in coffee$H$. vastatrix interactions lack a comprehensive study, but some clues have been disclosed by the expression profile of some phytohormone pathways-related genes. The regulation of 
genes related to ethylene pathway (ACC oxidase-CaACO1, ethylene-responsive element binding factor 2-CaERB2, Ethylene-responsive transcription factor $1 \mathrm{~B}-\mathrm{CaERF}$ ) and JA biosynthesis (allene oxide synthase-CaAOS, lipoxygenase-Ca9-LOX and Ca13-LOX) did not show clear evidence of the involvement of these phytohormones in the early coffee resistance responses to rust [140,142,151-153,155]. However, the activation of phenylalanine ammonia lyase $(P A L)$, a SA biosynthesis gene and the non-expressor of pathogenesisrelated gene (NPR1) a well-known SA-mediated protein-protein interactions, suggest that SA plays a key role in coffee defense to $H$. vastatrix $[140,154,173]$. Moreover, the simultaneous quantification of SA, JA and ABA in C. arabica leaves by LC/ESI-MS/MS showed an early increase in SA level in an incompatible interaction, while no significant variation was obtained for JA and ABA [145]. The pathogenesis-related proteins (PRs) genes, CaPR1, CaPR2, CaPR5, have also been associated with the induction of the SA pathway during the coffee immune response [140,142,143,152-154]. Up-regulation of PR10 was also found in incompatible coffee- $H$. vastatrix interactions $[140,143]$. Most of the PR10 are intercellular proteins with RNase activity, which could provide protection to plants during HR in the infected area's surroundings, while directly inhibiting pathogen development [174]. However, PRs are relevant elements of the defense response machinery, many with antimicrobial functions, such as, PR2 ( $\beta-1,3$-glucanase), PR3 (chitinases) and PR5 (thaumatin-like) $[175,176]$. An early increase of chitinase and glucanase activity in coffee- $H$. vastatrix incompatible interactions, but not in the compatible ones, was observed by Maxemiuc-Naccache et al. [148] using crude extracts of coffee leaves. Similar results were obtained when studying chitinase activity in intercellular fluids (IF), particularly the early increase in the cationic isoforms detected in the incompatible coffee-rust interactions. Immunodetection analyses performed with antibodies specific to class I chitinases revealed, again, the importance of these cationic isoforms in the incompatible interactions [147]. The proteomic analysis of the apoplastic coffee leaf proteins (which comprises cell wall and IF proteins) revealed that resistance was associated with an early increase of PR proteins, such as chitinases, thaumatin/osmotin, germin-like proteins (PR15 and PR16) and proteases (serine, cysteine and aspartic peptidases involved in protein degradation). Later, in the infection process the cell wall glycohydrolase (GHs) and other enzymes seem to play an important role in the coffee defense response (Table 3, Figure 3) [141]. Proteases, together with phosphatases, lead to a complex regulation of cell wall proteins through PTMs (post-translational modifications) that may affect PRR recognition and PR proteins with antifungal activity acting directly on pathogen inhibition/degradation. In addition, GHs confer great plasticity to cell wall polysaccharides, which in association with berberine bridge enzyme (reticulin oxidase -like), germin-like protein [oxalate oxidase or superoxide dismutase (SOD)-like] and other oxidative enzymes, can be involved in the cell wall cross-linking between phenolic compounds, polysaccharides and glycoproteins [141].

Oxidases have also been associated with the production of ROS via oxygen consumption in a so-called "oxidative burst" initiated in early defense reactions [177,178]. The oxidative burst involves a strictly controlled accumulation of ROS primarily composed of hydrogen peroxide $\left(\mathrm{H}_{2} \mathrm{O}_{2}\right)$ and superoxide $\left(\mathrm{O}_{2}{ }^{-}\right)$in host cells following pathogen recognition $[179,180]$. Given its membrane permeability and affinity to several signaling molecules such as SA and nitric oxide (NO), the rapid production of ROS, such as $\mathrm{H}_{2} \mathrm{O}_{2}$, can act as secondary messengers in defense-related signaling pathways, providing additional regulatory functions in plant defense responses $[179,180]$. Whether ROS acts as a damaging or signaling molecule depends on the delicate equilibrium between ROS production and scavenging. In plants, major ROS-scavenging mechanisms include catalase, ascorbate peroxidases, and SOD enzymes [181]. The oxidative burst occurs as a biphasic ROS accumulation in plant-pathogen interactions. The first phase is an unspecific, low, and transient reaction occurring in both compatible and incompatible interaction. The second sustained phase with much higher magnitude depends on the recognition of the pathogen's Avr genes, assisting the establishment of disease resistance $[39,180]$. Based on light microscopic studies, Ramiro et al. [143] reported a biphasic accumulation of $\mathrm{H}_{2} \mathrm{O}_{2}$, which was detected 
in a few stomatal cells from 15 hpi (hours post inoculation) and no differences were found between coffee- $H$. vastatrix incompatible and compatible interactions until 39 hpi. However, from this time point, intense DAB (3,3-diaminobenzidine) staining was observed in stomatal cells and adjacent epidermal cells of the coffee resistant genotype. Transmission electron microscope observations (following DAB treatments) revealed the localization of $\mathrm{H}_{2} \mathrm{O}_{2}$ in walls, middle lamellae, cytoplasmic contents and chloroplasts of stomatal coffee cells at the infection sites [136]. In addition to $\mathrm{H}_{2} \mathrm{O}_{2}$, the involvement of the superoxide anion radical $\mathrm{O}_{2}{ }^{-}$in $\mathrm{HR}$ was suggested by the significant inhibition of cell death after the treatment of coffee resistant leaves with ROS scavengers [144].

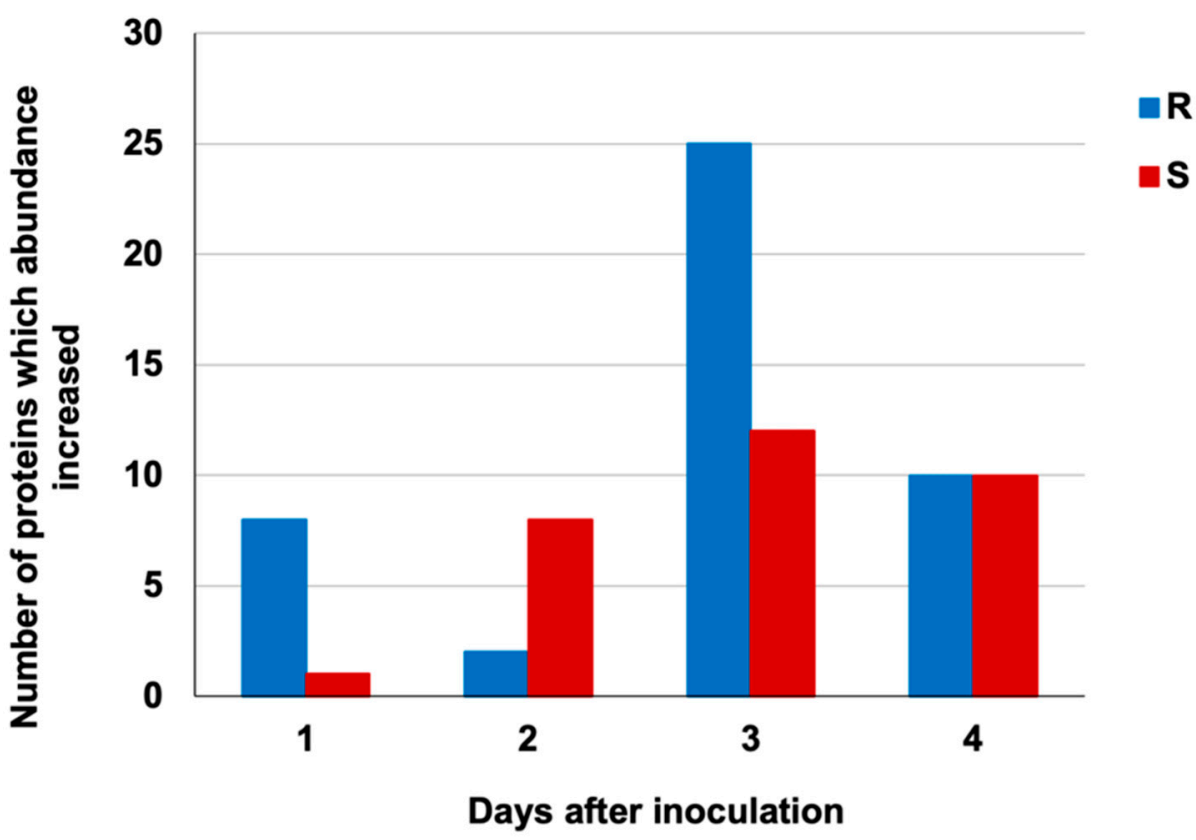

Figure 3. Number of leaf apoplastic proteins in which abundance increased in resistant (R) and susceptible (S) coffee samples obtained by proteomic analysis at 1, 2, 3, and 4 days after inoculation with Hemileia vastatrix [141]. Data show a biphasic increase in the number of proteins and a higher number of proteins changing in abundance in the resistance than in the susceptibility.

In some forms of HR, the rapid loss of cell membrane integrity is associated with ROS production and an increase in oxidizing enzymes, such as peroxidases and lipoxygenases (LOX) $[36,177,182]$. In incompatible coffee- $H$. vastatrix interactions, the induction of a cationic peroxidase gene (PNC2) was reported [151]. These observations are in line with the increase in POD activity of a new cationic isoform detected in isoelectric focusing gels [136]. Furthermore, the evaluation of the total POD activity in crude extracts revealed a peak of POD activity prior, or at the same time, as the beginning of HR in coffee- $H$. vastatrix incompatible interactions. A later increase of POD activity was also detected, being related to host cell wall lignification [136]. Additionally, the treatment of resistant coffee leaves with 2,4-dichlorophenol, an activator of peroxidases and other oxidases, resulted in a significant increase in cell death (HR). On the contrary, salicylhydroxamic acid, an inhibitor of the same enzymes and diphenyleneiodonium chloride, an inhibitor of NADPH oxidases, decreased cell death. These results suggest that the POD, NADPH oxidases, and eventually other oxidases, are involved in the HR of the coffee-rust interaction [136,144]. In an incompatible interaction a peak in total SOD activity was detected before cell death. The SOD isoenzymes pattern obtained by isoelectric focusing electrophoresis suggested that this could be attributed to isoenzymes with a pI between 4.7 and 5.4 [139]. In an incompatible coffee-rust interaction, LOX activity increased during the hypersensitive response. In contrast, the enzyme activity remained moderately constant in the compatible interaction [183]. LOXs catalyze the conversion of polyunsaturated fatty acids such as 
linoleic acid into hydroperoxides, which may cause oxidative damage to plant membranes during the HR $[149,184]$.

Plant phenolics are secondary metabolites consisting of structurally diverse compounds arising from shikimate-phenylpropanoid pathways. Several studies suggest that they are strongly involved in plant-pathogen interactions and may restrict the spread of a pathogen [185]. PAL is a key enzyme of the phenylpropanoid pathway that catalyzes the deamination of phenylalanine to trans-cinnamic acid, a precursor for SA, lignin and flavonoid biosynthetic pathways [186]. Lignin is a major phenolic polymer present in the secondary cell wall of vascular plants, and in addition to its roles in growth and development, it has been suggested to be a physical barrier against pathogens [187]. In coffee plants resistant to $H$. vastatrix, PAL activity revealed two peaks; one detected two days after inoculation, coincident with an early accumulation of phenolic-like compounds in the cell walls and cytoplasm, and the beginning of HR. A second peak was observed 5 days after inoculation that could be related to a later accumulation of phenolic compounds, and the host cell wall lignification, as confirmed by the phloroglucinol-HCl test [52,137]. Indeed, the quantification of chlorogenic acids (CGAs) performed by HPLC-DAD and LC-MS, which are also products of phenylpropanoid metabolism, was abundantly identified in coffee [188]. An early and significant increase of CGAs content, particularly 4,5-diCQA (4,5dicaffeoylquinic acid), was observed in an incompatible $\mathrm{C}$. arabica- $\mathrm{H}$. vastatrix interaction comparatively to the compatible one and the control (healthy leaves) [189].

Haustoria encasement is another early host response observed in coffee- $H$. vastatrixincompatible interactions. However, this response is also observed in compatible interactions, but later on, from the seventh day after inoculation, and in a small number of haustoria [52,137,142]. Cyto- and immunocytochemical studies revealed that haustoria are encased by material that reacted positively for callose and for $\beta-1,4$-glucans. Pectins are also localized around the penetration pegs, but not around haustorial bodies [51,137]. Encasement might have a role in plant defense by serving as a barrier to block effective uptake of host nutrients through haustoria and inhibiting the pathogen's effector delivery $[146,190]$.

At advanced stages of the infection (around 5-7 days after the inoculation), transmission electron microscope observations of samples from C. arabica and C. congensis resistant plants [137] showed an intriguing accumulation of partially crystallised material in the intercellular spaces around the senescent hyphae, next to dead host cells and in close association with the middle lamella. That material was never detected in healthy or susceptible tissues. Cyto and immunocytochemical tests showed that at the beginning of accumulation, that material contained weakly esterified pectins. That material was also composed of polysaccharides as judged by PATAg test and phenolic-like compounds, as evidenced by autofluorescence. Cellulose, hemicellulose, HRGPs, and proteins were not detected. Although the role of this material is unknown, it might be the result of plant cell death associated with the slowdown of tissue invasion by the pathogen [52,137].

Hypertrophy of the mesophyll cells at the infection sites is a cytological response observed in different coffee resistant genotypes, from 6 days after inoculation $[20,52,137]$, suggesting the possible involvement of growth regulators. The first cells to increase in size are those subjacent to the sub-stomatal chamber, and later all the spongy cells become irregularly shaped and some of them with thicker walls. Their nuclei also increase in volume $(1.5 \times)$ as do the nucleoli $(2-3 \times)$. The palisade parenchyma does not show any morphological alterations. During the cell volume increasement, the fungal hyphae are apparently crushed between the cells [20]. Those bigger cells give rise to a localized tumefaction and corresponded macroscopically to the reaction type flt (small chlorotic flecks associated with punctiform tumefactions). This reaction type is also observed in nonhost species of the Rubiaceae family [as revised by 137].

Most of the described responses induced by $H$. vastatrix occur in incompatible and compatible interactions, but earlier and with greater magnitude during the resistance response, particularly in pre-haustorial resistance. 


\section{Systemic-Acquired Resistance (SAR) in Coffee}

The best characterized type of induced resistance mechanism is systemic-acquired resistance [191]. As an integral part of SAR, priming is a plant physiological state able to raise the activation of stress-induced defense responses. It has no or minimal negative impact on the host plants' energy status since primed plants deploy their defense repertoire only during pathogen attack, and not in a constitutive manner [42].

The activation of SAR by the application of plant resistance inducers (PRIs) that mimic a pathogen infection results in a stronger and faster defense response when biotic and abiotic stresses occur. Different PRI treatments, either chemical agents, extracts from plants or microbes have been used [192].

In coffee plants, protection against coffee leaf rust was achieved by treatments with different PRIs such as yeast extract [193], Bacillus thuringiensis [194,195], exopolysaccharides from bacterial cells of Xanthomonas campestris [196], acibenzolar-S-methyl (ASM-salicylic acid functional analog belonging to the benzothiadiazole (BTH) family) [153,197], potassium silicate [198], phosphites [199] and formulations based on natural products [200-202]. In field trials some of these PRIs used alone, combined, or in association with fungicides can significantly reduce CLR incidence [199-201]. The cellular mechanisms behind PRIS's effect on coffee leaves were studied using different molecular approaches. The increase in the enzymatic activities of chitinase and $\beta$-1,3-glucanase was observed after ASM treatment of coffee plants cv. Mundo Novo [153]. De Nardi et al. [203] used microarray hybridization to study the effect of BTH on coffee leaves. A shift from housekeeping to defense metabolism was found in BTH-treated leaves, with an increase in pathogenesis-related protein, oxidative burst and in cell wall strengthening processes. The coffee genes associated with SAR against CLR identified by suppression subtractive hybridization after ASM treatment [153] were involved in the oxidative burst, hypersensitive response, synthesis of antimicrobial proteins, synthesis and transport of antimicrobial metabolites, signal perception and transduction, metabolism of lipids, regulated protein degradation and cell maintenance and development.

In coffee leaves treated with phosphites (inorganic salts of phosphorous acid), the induction of the expression of defense-related genes, such as peroxidase, catalase, $\beta-1.3$ glucanase and PAL, was reported [199]. Biochemical studies further confirmed the increase in the activity of antioxidant enzymes (ascorbate peroxidase, superoxide dismutase, catalase and polyphenol oxidase) [199,204] and the photosynthetic rates of treated leaves [204]. Recently, a physiological (leaf gas-exchange), biochemical (enzymatic) and proteomic study was undertaken. Coffee leaves were treated with Greenforce $\mathrm{CuCa}$ (formulation prepared with coffee industry by-products supplemented with calcium and copper salts), ASM and inoculated with $H$. vastatrix [202]. Both PRIs prepared the plant to resist CLR, but they induced different mechanisms upon pathogen infection. Greenforce $\mathrm{CuCa}$ treatment showed an increase in stomatal conductance and photosynthetic rate, and it further reinforced the redox homeostasis of the leaf, while ASM seemed to affect preferentially the secondary metabolism and stress-related proteins.

A protection strategy that takes advantage of the plant immune system by eliciting constitutive defenses could be an alternative solution (replacing the fungicide treatments) for more sustainable coffee production management [205].

\section{Conclusions and Perspectives}

This review summarizes the progress made to date in the research of coffee- $H$. vastatrix interactions from both the plant and pathogen viewpoints. Extensive inheritance studies performed in the sixties represented a crucial milestone by showing that coffee- $H$. vastatrix interactions follow the Flor's gene-for-gene model. Based on this model, more than 55 rust races have been identified so far, according to their virulence spectra, on a set of defined coffee differentials. Molecular diversity among rust isolates has been reported, although a link with their phenotypic diversity has not yet been established. Nevertheless, recent 
efforts in H. vastatrix genomic research may provide candidate markers associated with specific rust races in the near future.

The integration of recent advances in "omics" (including genomics, transcriptomics, effectoromics, and proteomics) upheld by phenotyping assays can fasten the identification of putative $H$. vastatrix effectors and the characterization of their virulence/avirulence functions in coffee. Up to now, only one candidate effector has been functionally validated, mainly due to technical difficulties posed by both the pathogen and the host, which makes it necessary to use heterologous systems. Future challenges include the implementation of assays to study effector's functions and the identification of plant cognate resistance genes, which will result in a deeper understanding of plant-pathogen "cross-talks", and H. vastatrix's effector biology and its importance in pathogenicity. Altogether, this knowledge will help unveil $R$ genes with the potential to accelerate and improve screening for disease resistance in coffee breeding.

In the late 1950s, a breakthrough for controlling CLR by resistant varieties was the discovery of HDT genotypes with resistance to all known rust races. This source of resistance was used by all coffee breeding programs allowing the release of the majority of resistant varieties grown nowadays. However, the resistance of some of these varieties has been progressively overcome due to the emergence of more virulent rust races, highlighting the dynamic nature of the plant and pathogen co-evolution. Entering into what seems to be a new cycle in CLR resistance, the identification, and characterization of new sources of resistance is crucial to face also the emergent epidemic resurgence of this disease in Latin America and the Caribbean, which is considered a natural disaster in the tropics.

This review updates the knowledge on the complex multilayer defense mechanisms of coffee to $H$. vastatrix, based on detailed studies that have been instrumental to elucidate several processes using cytological, biochemical, analytical chemistry, gene expression analysis, and various omics tools (as summarized in Figure 4).

Coffee resistance is characterized by restricted fungal growth (pre- or post-haustorial resistance) associated with several plant responses: the hypersensitive response, accumulation of ROS, haustoria encasement with callose and $\beta-1,4$-glucans, deposition of phenolic-like compounds, cell wall lignification, intercellular accumulation of pectin-like material also composed of polysaccharides and phenolic compounds, and cell hypertrophy. Additionally, the increase in the activity of oxidative enzymes [e.g., peroxidases (POD), lipoxygenase (LOX), and superoxide dismutase SOD)], phenylalanine ammonialyase (PAL), $\beta-1,3$-glucanase, and chitinases have been also detected. The apoplastic coffee proteome analysis revealed proteases (subtilisin, cysteine-like, serine and aspartic-like), hydrolases, and oxidases associated with coffee resistance. Within this complex cascade of events occurring upon rust infection, the salicylic acid-dependent pathway seems to play a decisive role mediating the coffee resistance response. Genes putatively involved in pathogen recognition, signaling, and defense have been identified in coffee- $H$. vastatrix interactions, such as, receptor kinases, subtilisin-like protease, WRKY transcription factors, glucosyltransferases, phenylalanine ammonia-lyase, and PRs. Furthermore, similar coffee defense responses induced by $H$. vastatrix have been observed using plant resistance inducers. Interestingly, resistant and susceptible coffee genotypes share the same type of responses when infected by H. vastatrix. However, these are observed earlier and with greater magnitude during the resistance response, particularly in pre-haustorial resistance. In fact, in HDT genotypes used as resistance sources in breeding programs, such as HDT832/2, pre-haustorial resistance mechanisms, show longer durability. 


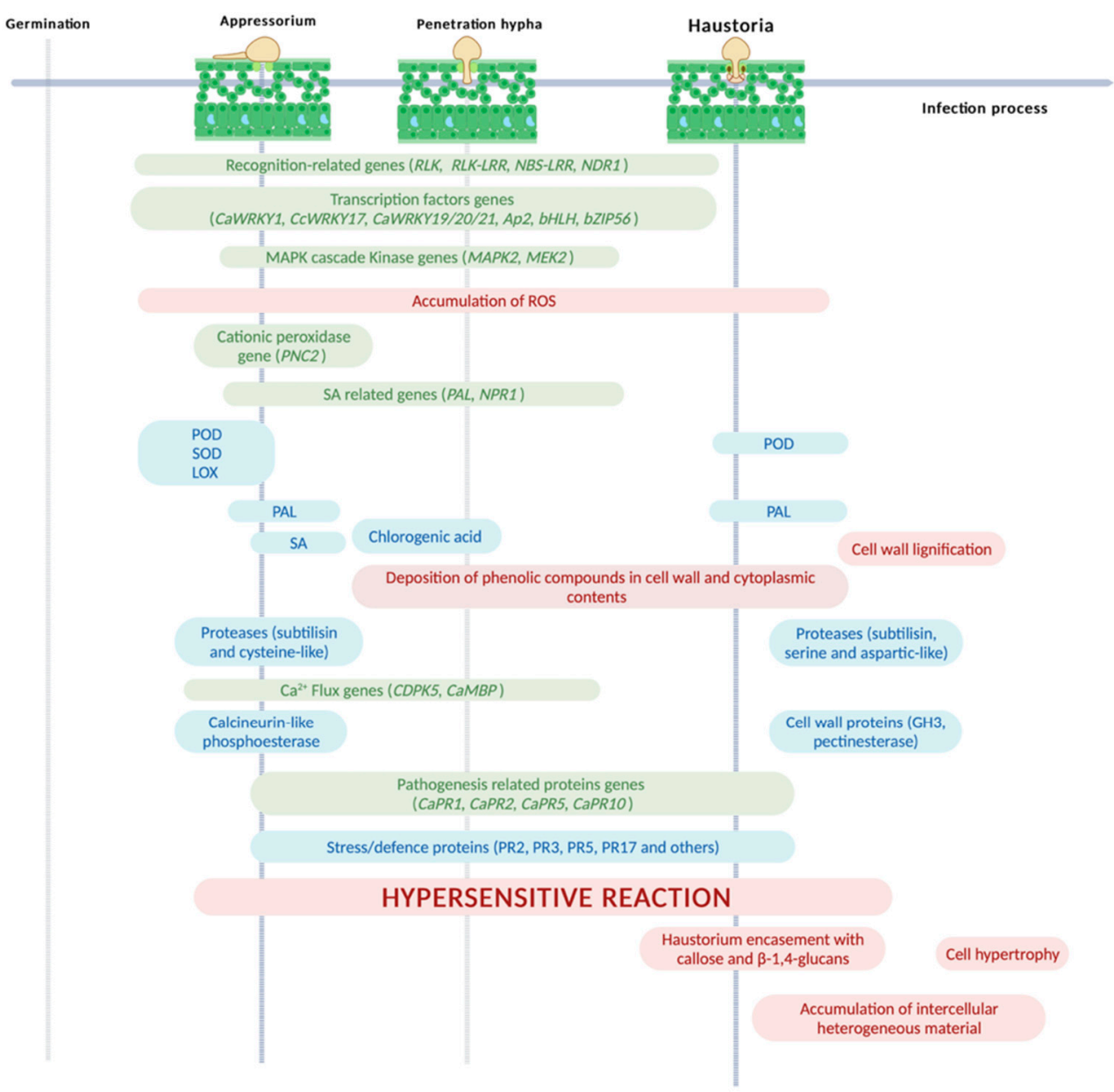

Figure 4. Schematic model of coffee defense responses of Coffea spp. to Hemileia vastatrix. The activation of genes, proteins and metabolites and cytological responses are indicated in green, blue and pink colors, respectively. RLK, receptor-like kinase; LRR-RLK, Leucine-rich repeat receptorlike kinase; NBS-LRR, nucleotide-binding site receptor-like kinase; NDR1, non-race specific disease resistance 1; WRKY's (WRKY1, WRKY17, WRKY19/20/21) WRKY transcription factor; Ap2, AP2 type transcription factor; bHLH, basic helix-loop-helix DNA- binding protein; bZIP56, bZIP transcription factor; MAPK2, mitogen-activated protein kinase 2; MEK2, mitogen-activated protein kinases 2; ROS, reactive oxygen species; PNC2, cationic peroxidase gene; PAL, phenylalanine ammonia lyase; NPR1, non-expressor of pathogenesis-related gene; POD, peroxidase; SOD, Superoxide dismutase, LOX, lipoxygenase; SA, Salicylic acid; GH3, glycoside hydrolase class 3; CDPK5, calcium-dependent protein kinase 5; CaMBP, calmodulin-binding protein; PR's (PR1, PR22, PR5, PR10) pathogenesis-related genes. Created with Biorender.com, access date 24 December 2021.

Although a better understanding of the cellular, biochemical, and molecular mechanisms of host resistance has been achieved, hard work still lies ahead for the research community working on coffee resistance, regarding a deep lack of information on resistance genes at all levels from identification and function to regulation. Given the current availability of genomic and EST data, candidate genes potentially involved in coffee-pathogen interactions have been identified, and it is expected that these resources will provide the opportunity to increase their number in a near future, allowing subsequent studies at the functional genomics level. Deep-sequencing has led to the discovery of several hundred small non-coding RNA (sRNA, miRNAs) involved in gene regulation, such as those required for immunity (R-genes). Although only recently, miRNA analyses in C. arabica$H$. vastatrix interactions began to be unveiled [206], some miRNA families were identified as putative candidates for the mediation of coffee resistance and susceptibility, for which 
putative targets were predicted but not yet validated. The characterization of miRNAs may shed light on the mechanisms that drive coffee resistance and susceptibility to CLR.

Regardless of all the significant advances obtained so far, in-depth research on coffee$H$. vastatrix interactions driven by new advanced technologies is still crucial for developing efficient disease resistance breeding and new strategies for crop protection. As new and more powerful genomic resources become available, we have the opportunity to not only decipher the complexity of resistance processes, but also to revisit hypotheses previously generated.

Supplementary Materials: The following supporting information can be downloaded at: https:// www.mdpi.com/article/10.3390/agronomy12020326/s1. Table S1: All genes putatively involved in coffee interaction to Hemileia vastatrix based on RT-qPCR analysis.

Author Contributions: Conceptualization, M.d.C.S.; writing—original draft preparation, M.d.C.S., L.G.-G., I.D., A.L., H.A., A.P.P., S.T., D.B., V.V.; writing-review \& editing, M.d.C.S., L.G.-G., I.D., A.L., H.A., A.P.P., S.T., D.B., V.V. All authors have read and agreed to the published version of the manuscript.

Funding: This research was co-funded by Foundation for Science and Technology (FCT) and FEDER funds through PORNorte under the project CoffeeRES ref. PTDC/ASP-PLA/29779/2017, and through PORLisboa, under the project PATHOmics ref. PTDC/ASP-PLA/29189/2017, and by FCT UNIT LEAF (UID/AGR/04129/2020).

Conflicts of Interest: The authors declare no conflict of interest.

\section{References}

1. International Coffee Organization (ICO). Coffee Development Report 2019 Overview; International Coffee Organization: London, UK, 2019.

2. Davis, A.P.; Tosh, J.; Ruch, N.; Fay, M. Growing coffee: Psilanthus (Rubiaceae) subsumed on the basis of plastid and nuclear DNA sequences; implication for the size, morphology, distribution and evolutionary history of Coffea. Bot. J. Linn. Soc. 2011, 167, 357-377. [CrossRef]

3. Charrier, A.; Berthaud, J. Botanical classification of coffee. In Coffee: Botany, Biochemistry and Production of Beans and Beverage; Clifford, M.N., Wilson, K.C., Eds.; Croom Helm: London, UK; Sydney, Australia, 1985; ISBN 978-1-4615-6659-5.

4. International Coffee Organization (ICO). ICO Coffee Production 2020. Available online: https://www.ico.org/prices/poproduction.pdf (accessed on 29 December 2021).

5. Davis, A.P.; Chadburn, H.; Moat, J.; O'Sullivan, R.; Hargreaves, S.; Lughadha, E.N. High extinction risk for wild coffee species and implications for coffee sector sustainability. Sci. Adv. 2019, 5, eaav3473. [CrossRef] [PubMed]

6. van der Vossen, H.; Bertrand, B.; Charrier, A. Next generation variety development for sustainable production of arabica coffee (Coffea arabica L.): A review. Euphytica 2015, 204, 243-256. [CrossRef]

7. Talhinhas, P.; Batista, D.; Diniz, I.; Vieira, A.; Silva, D.N.; Loureiro, A.; Tavares, S.; Pereira, A.P.; Azinheira, H.G.; Guerra-Guimarães, L.; et al. Pathogen profile-The coffee leaf rust pathogen Hemileia vastatrix: One and a half centuries around the tropics. Mol. Plant Pathol. 2017, 18, 1039-1051. [CrossRef] [PubMed]

8. Avelino, J.; Allinne, C.; Cerda, R.; Willocquet, L.; Savary, S. Multiple-disease system in coffee: From crop loss assessment to sustainable management. Annu. Rev. Phytopathol. 2018, 56, 611-635. [CrossRef] [PubMed]

9. Maghuly, F.; Jankowicz-Cieslak, J.; Bado, S. Improving coffee species for pathogen resistance. CAB Rev. 2020, 15, 1-18. [CrossRef]

10. Kahn, L.H. Quantitative framework for coffee leaf rust (Hemileia vastatrix), production and futures. Int. J. Agric. Ext. 2019, 7, 77-87. [CrossRef]

11. Bettencourt, A.J.; Rodrigues, C.J. Principles and practice of coffee breeding for resistance to rust and other diseases. In Coffee Agronomy; Clarke, R.J., Macrae, R., Eds.; Elsevier Applied Science Publishers LTD: London, UK; New York, NY, USA, 1988; Volume 4, pp. 199-234.

12. McCook, S.; Peterson, P.D. The geopolitics of plant pathology: Frederick Wellman, coffee leaf rust, and cold war networks of science. Annu. Rev. Phytopathol. 2020, 58, 181-199. [CrossRef]

13. Wellman, F. Peligro de introducción de la Hemileia del café a las Américas. Turrialba 1952, 2, 47-50.

14. Keith, L.; Sugiyama, L.; Brill, E.; Adams, B.-L.; Fukada, M.; Hoffman, K.; Ocenar, J.; Kawabata, A.; Kong, A.; McKemy, J.; et al. First report of coffee leaf rust caused by Hemileia vastatrix on coffee (Coffea arabica) in Hawaii. Plant Dis. 2021, 34, 2-4. [CrossRef]

15. Baker, P. The 'Big Rust': An update on the coffee leaf rust situation. Coffee Cocoa Int. 2014, 40, 37-39.

16. Avelino, J.; Cristancho, M.; Georgiou, S.; Imbach, P.; Aguilar, L.; Bornemann, G.; Läderach, P.; Anzueto, F.; Hruska, A.J; Morales, C. The coffee rust crises in Colombia and Central America (2008-2013): Impacts, plausible causes and proposed solutions. Food Secur. 2015, 7, 303-321. [CrossRef] 
17. McCook, S.; Vandermeer, J. The Big Rust and the Red Queen: Long-term perspectives on coffee rust research. Phytopathology 2015, 105, 1164-1173. [CrossRef]

18. Rhiney, K.; Guido, Z.; Knudson, C.; Avelino, J.; Bacon, C.M.; Leclerc, G.; Aime, M.C.; Bebber, D.P. Epidemics and the future of coffee production. Proc. Natl. Acad. Sci. USA 2021, 118, e2023212118. [CrossRef]

19. Noronha-Wagner, M.; Bettencourt, A.J. Genetic study of the resistance of Coffea spp. to leaf rust. Can. J. Bot. 1967, 45, 2021-2031. [CrossRef]

20. Rodrigues, C.J.; Bettencourt, A.J.; Rijo, L. Races of the pathogen and resistance to coffee rust. Annu. Rev. Phytopathol. 1975, 13, 49-70. [CrossRef]

21. Várzea, V.M.P.; Marques, D.V. Population variability of Hemileia vastatrix vs. coffee durable resistance. In Durable Resistance to Coffee Leaf Rust; Zambolim, L., Zambolim, E., Várzea, V.M.P., Eds.; Universidade Federal de Viçosa: Viçosa, Brasil, 2005; pp. 53-74.

22. De Almeida, D.P.; Samila, I.; Castro, L.; Antônio, T.; Mendes, D.O.; Alves, D.R. Receptor-Like Kinase (RLK) as a candidate gene conferring resistance to Hemileia vastatrix in coffee. Sci. Agric. 2021, 78, e20200023. [CrossRef]

23. Bettgenhaeuser, J.; Gilbert, B.; Ayliffe, M.; Moscou, M.J. Nonhost resistance to rust pathogens-A continuation of continua. Front. Plant Sci. 2014, 5, 664. [CrossRef]

24. Li, P.; Lu, Y.J.; Chen, H.; Day, B. The lifecycle of the plant immune system. Crit. Rev. Plant Sci. 2020, 39, 72-100. [CrossRef]

25. Nishad, R.; Ahmed, T.; Rahman, V.J.; Kareem, A. Modulation of plant defense system in response to microbial interactions. Front. Microbiol. 2020, 11, 1298. [CrossRef]

26. Jones, J.D.G.; Dangl, J.L. The plant immune system. Nature 2006, 444, 323-329. [CrossRef] [PubMed]

27. Upson, J.L.; Zess, E.K.; Białas, A.; Wu, C.H.; Kamoun, S. The coming of age of EvoMPMI: Evolutionary molecular plant-microbe interactions across multiple timescales. Curr. Opin. Plant Biol. 2018, 44, 108-116. [CrossRef] [PubMed]

28. De Wit, P.J.G.M.; Mehrabi, R.; Van Den Burg, H.A.; Stergiopoulos, I. Fungal effector proteins: Past, present and future: Review. Mol. Plant Pathol. 2009, 10, 735-747. [CrossRef] [PubMed]

29. Zipfel, C. Plant pattern-recognition receptors. Trends Immunol. 2014, 35, 345-351. [CrossRef]

30. Han, G.Z. Origin and evolution of the plant immune system. New Phytol. 2019, 222, 70-83. [CrossRef]

31. Flor, H.H. Current status of the gene-for-gene concept. Annu. Rev. Phytopathol. 1971, 9, 275-297. [CrossRef]

32. Lang, J.; Colcombet, J. Sustained incompatibility between MAPK signaling and pathogen effectors. Int. J. Mol. Sci. 2020, 21, 7954. [CrossRef]

33. Ravensdale, M.; Bernoux, M.; Ve, T.; Kobe, B.; Thrall, P.H.; Ellis, J.G.; Dodds, P.N. Intramolecular interaction influences binding of the flax L5 and L6 resistance proteins to their AvrL567 ligands. PLoS Pathog. 2012, 8, e1003004. [CrossRef]

34. Peng, Y.; Van Wersch, R.; Zhang, Y. Convergent and divergent signaling in PAMP-triggered immunity and effector-triggered immunity. Mol. Plant-Microbe Interact. 2018, 31, 403-409. [CrossRef]

35. Balint-Kurti, P. The plant hypersensitive response: Concepts, control and consequences. Mol. Plant Pathol. 2019, 20 , 1163-1178. [CrossRef]

36. Heath, M.C. Hypersensitive response-related death. Plant Mol. Biol. 2000, 44, 321-334. [CrossRef]

37. Andersen, E.J.; Ali, S.; Byamukama, E.; Yen, Y.; Nepal, M.P. Disease resistance mechanisms in plants. Genes 2018, 9, 339. [CrossRef]

38. Periyannan, S.; Milne, R.J.; Figueroa, M.; Lagudah, E.S.; Dodds, P.N. An overview of genetic rust resistance: From broad to specific mechanisms. PLoS Pathog. 2017, 13, e1006380. [CrossRef]

39. Martins, D.; Araújo, S.D.; Rubiales, D.; Patto, M.C.V. Legume crops and biotrophic pathogen interactions: A continuous cross-talk of a multilayered array of defense mechanisms. Plants 2020, 9, 1460. [CrossRef]

40. Metraux, J. Systemic acquired resistance and salicylic acid: Current state of knowledge. Eur. J. Plant Pathol. 2001, 107, 13-18. [CrossRef]

41. Cavalcanti, F.R.; Resende, M.L.V.; Carvalho, C.P.S.; Silveira, J.A.G.; Oliveira, J.T.A. Induced defence responses and protective effects on tomato against Xanthomonas vesicatoria by an aqueous extract from Solanum lycocarpum infected with Crinipellis perniciosa. Biol. Control 2006, 39, 408-417. [CrossRef]

42. Balmer, A.; Pastor, V.; Gamir, J.; Flors, V.; Mauch-Mani, B. The "prime-ome": Towards a holistic approach to priming. Trends Plant Sci. 2015, 20, 443-452. [CrossRef]

43. Gozzo, F.; Faoro, F. Systemic acquired resistance (50 years after discovery): Moving from the lab to the field. J. Agric. Food Chem. 2013, 61, 12473-12491. [CrossRef]

44. De Resende, M.L.V.; Pozza, E.A.; Reichel, T.; Botelho, D.M.S. Strategies for coffee leaf rust management in organic crop systems. Agronomy 2021, 11, 1865. [CrossRef]

45. Heath, M.C. Signalling between pathogenic rust fungi and resistant or susceptible host plants. Ann. Bot. 1997, 80, 713-720. [CrossRef]

46. Voegele, R.T.; Mendgen, K.W. Nutrient uptake in rust fungi: How sweet is parasitic life? Euphytica 2011, 179, 41-55. [CrossRef]

47. Catanzariti, A.M.; Dodds, P.N.; Lawrence, G.J.; Ayliffe, M.A.; Ellis, J.G. Haustorially expressed secreted proteins from flax rust are highly enriched for avirulence elicitors. Plant Cell 2006, 18, 243-256. [CrossRef]

48. Garnica, D.P.; Nemri, A.; Upadhyaya, N.M.; Rathjen, J.P.; Dodds, P.N. The ins and outs of rust haustoria. PLoS Pathog. 2014, 10, e1004329. [CrossRef]

49. Mendgen, K.; Voegele, R. Biology of rusts and mechanisms of infection. In Durable Resistance to Coffee Leave Rust; Zambolim, L., Zambolim, E.M., Várzea, V., Eds.; Universidade Federal de Viçosa: Viçosa, Brasil, 2005; pp. 233-248. 
50. Azinheira, H.G.; Guerra-Guimarães, L.; Silva, M.C.; Várzea, V.; Ricardo, C.P. Esterase activity and adhesion during the early stages of Hemileia vastatrix differentiation. In Proceedings of the 21st International Conference on Coffee Science (ASIC), France, Montpellier, 11-15 September 2006; pp. 1325-1329.

51. Silva, M.C.; Nicole, M.; Rijo, L.; Geiger, J.P.; Rodrigues, C.J. Cytochemistry of plant- rust fungus interface during the compatible interaction Coffea arabica (cv. Caturra)-Hemileia vastatrix (race III). Int. J. Plant Sci. 1999, 160, 79-91. [CrossRef]

52. Silva, M.C.; Várzea, V.; Guerra-Guimarães, L.; Azinheira, H.G.; Fernandez, D.; Petitot, A.S.; Bertrand, B.; Lashermes, P.; Nicole, M. Coffee resistance to the main diseases: Leaf rust and coffee berry disease. Braz. J. Plant Physiol. 2006, 18, 119-147. [CrossRef]

53. Cramer, P.J.S. Review of literature of coffee research in Indonesia. Inter-Am. Inst. Agric. Sci. Misc. Publ. 1952, 15, 262.

54. Narasimhaswamy, R.L. Coffee leaf disease (Hemileia) in India. Indian Coffee 1961, 25, 382-388.

55. Mayne, W.W. Physiological specializalion of Hemileia vastatrix. B. \& Br. Nature 1932, 129, 510. [CrossRef]

56. Mayne, W.W. Annual report of the coffee scientific officer 1938-39. Mys. Coffee Exp. Stn. 1939, 19, 1-16.

57. Zhang, H.; Li, J.; Zhou, H.; Chen, Z.; Pereira, A.P.; Silva, M.C.; Várzea, V. Arabica coffee production in the Yunnan province of China. In Proceedings of the 24th International Conference on Coffee Science (ASIC), San José, Costa Rica, 12-16 November 2012; pp. 679-684.

58. Noppakoonwong, U.; Khomarwut, C.; Hanthewee, M.; Jarintorn, S.; Hassarungsee, S.; Meesook, S.; Daoruang, C.; Nakai, P.; Lertwatanakiat, S.; Satayawut, K.; et al. Research and Development of Arabica Coffee in Thailand. In Proceedings of the 25th International Conference on Coffee Science (ASIC), Armenia, Colombia, 8-13 September 2014; pp. 42-49.

59. Gichuru, E.K.; Ithiru, J.M.; Silva, M.C.; Pereira, A.P.; Várzea, V.M.P. Additional physiological races of coffee leaf rust (Hemileia vastatrix) identified in Kenya. Trop. Plant Pathol. 2012, 37, 424-427. [CrossRef]

60. Oliveira, B.; Bettencourt, A.J.; Rodrigues, C.J.; Rijo, L.; Azinheira, H.; Talhinhas, P.; Silva, M.C.; Várzea, V. Data Records of CIFC's Research, 1955-2021. Unpublished work.

61. Li, L.; Várzea, V.M.P.; Xia, Q.; Xiang, W.; Tang, T.; Zhu, M.; He, C.; Pereira, A.P.; Silva, M.C.; Wu, W.; et al. First report of Hemileia vastatrix (Coffee Leaf Rust) physiological races emergent in coffee germplasm collections in the coffee-Cropping regions of China. Plant Dis. 2021, 105, 4162. [CrossRef]

62. Tavares, S.; Ramos, A.P.; Pires, A.S.; Azinheira, H.G.; Caldeirinha, P.; Link, T.; Abranches, R.; Silva, M.D.; Voegele, R.T.; Loureiro, J.; et al. Genome size analyses of Pucciniales reveal the largest fungal genomes. Front. Plant Sci. 2014, 5, 422. [CrossRef]

63. Porto, B.N.; Caixeta, E.T.; Mathioni, S.M.; Vidigal, P.M.P.; Zambolim, L.; Zambolim, E.M.; Donofrio, N.; Polson, S.W.; Maia, T.A.; Chen, C.; et al. Genome sequencing and transcript analysis of Hemileia vastatrix reveal expression dynamics of candidate effectors dependent on host compatibility. PLoS ONE 2019, 14, e0215598. [CrossRef]

64. Cristancho, M.A.; Botero-Rozo, D.O.; Giraldo, W.; Tabima, J.; Riaño-Pachón, D.M.; Escobar, C.; Rozo, Y.; Rivera, L.F.; Durán, A.; Restrepo, S.; et al. Annotation of a hybrid partial genome of the coffee rust (Hemileia vastatrix) contributes to the gene repertoire catalog of the Pucciniales. Front. Plant Sci. 2014, 5, 594. [CrossRef]

65. Silva, D.N.; Várzea, V.; Paulo, O.S.; Batista, D. Population genomic footprints of host adaptation, introgression and recombination in coffee leaf rust. Mol. Plant Pathol. 2018, 19, 1742-1753. [CrossRef]

66. Rodrigues, A.S.; Silva, D.N.; Várzea, V.; Paulo, O.S. Scaled-up genomic data uncovers a higher level of population genetic structuring in Hemileia vastatrix. In Proceedings of the 28th International Conference on Coffee Science (ASIC), Montpellier, France, 28 June-1 July 2021; p. 40.

67. Guerra-Guimarães, L.; Pinheiro, C.; Leclercq, C.; Resende, M.L.V.; Jenny, J.; Ricardo, C.P.; Várzea, V. The first insight on the Hemileia vastatrix urediniospores proteome. In Proceedings of the 28th International Conference on Coffee Science (ASIC), Montpellier, France, 28 June-1 July 2021; p. 223.

68. Boufleur, T.R.; Massola Júnior, N.S.; Tikami, I.; Sukno, S.A.; Thon, M.R.; Baroncelli, R. Identification and comparison of Colletotrichum secreted effector candidates reveal two independent lineages pathogenic to soybean. Pathogens 2021, 10, 1520. [CrossRef]

69. Vleeshouwers, V.G.A.A.; Oliver, R.P. Effectors as tools in disease resistance breeding against biotrophic, hemibiotrophic, and necrotrophic plant pathogens. Mol. Plant-Microbe Interact. 2014, 27, 196-206. [CrossRef]

70. Gorash, A.; Armonienè, R.; Kazan, K. Can effectoromics and loss-of-susceptibility be exploited for improving Fusarium head blight resistance in wheat? Crop J. 2021, 9, 1-16. [CrossRef]

71. Fernandez, D.; Tisserant, E.; Talhinhas, P.; Azinheira, H.; Vieira, A.; Petitot, A.S.; Loureiro, A.; Poulain, J.; da Silva, C.; Silva, M.C.; et al. 454-pyrosequencing of Coffea arabica leaves infected by the rust fungus Hemileia vastatrix reveals in plantaexpressed pathogen-secreted proteins and plant functions in a late compatible plant-rust interaction. Mol. Plant Pathol. 2012, 13, 17-37. [CrossRef]

72. Talhinhas, P.; Azinheira, H.G.; Vieira, B.; Loureiro, A.; Tavares, S.; Batista, D.; Morin, E.; Petitot, A.-S.; Paulo, O.S.; Poulain, J.; et al Overview of the functional virulent genome of the coffee leaf rust pathogen Hemileia vastatrix with an emphasis on early stages of infection. Front. Plant Sci. 2014, 5, 88. [CrossRef]

73. Sperschneider, J.; Gardiner, D.M.; Dodds, P.N.; Tini, F.; Covarelli, L.; Singh, K.B.; Manners, J.M.; Taylor, J.M. EffectorP: Predicting fungal effector proteins from secretomes using machine learning. New Phytol. 2016, 210, 743-761. [CrossRef]

74. Sperschneider, J.; Dodds, P.N.; Gardiner, D.M.; Singh, K.B.; Taylor, J.M. Improved prediction of fungal effector proteins from secretomes with EffectorP 2.0. Mol. Plant Pathol. 2018, 19, 2094-2110. [CrossRef] 
75. Loureiro, A.; Tavares, S.; Azinheira, H.G.; Talhinhas, P.; Pereira, A.P.; Fernandez, D.; Silva, M.C. Identification and characterisation of Hemileia vastatrix effectors. In Proceedings of the 25th International Conference on Coffee Science (ASIC), Armenia, Colombia, 8-13 September 2014; p. 250.

76. Silva, M.C.; Guerra-Guimarães, L.; Azinheira, H.G.; Talhinhas, P.; Tavares, S.; Loureiro, A.; Diniz, I.; Vieira, A.; Pereira, A.P.; Oliveira, H.; et al. Mechanisms involved in coffee-Hemileia vastatrix interactions: Plant and pathogen perspectives. In Proceedings of the 26th International Conference on Coffee Science (ASIC), Kunming, China, 13-19 November 2016 ; p. 14.

77. Tavares, S.; Azinheira, H.G.; Voegele, R.; Thordal-Christensen, H.; Silva, M.; Talhinhas, P. Identification of Hemileia vastatrix candidate effectors reveals new ways of promoting pathogen variability through alternative splicing. In Proceedings of the 28th International Conference on Coffee Science (ASIC), Montpellier, France, 28 June-1 July 2021; p. 42.

78. Maia, T.; Badel, J.L.; Marin-Ramirez, G.; Rocha, C.d.M.; Fernandes, M.B.; da Silva, J.C.F.; de Azevedo-Junior, G.M.; Brommonschenkel, S.H. The Hemileia vastatrix effector HvEC-016 suppresses bacterial blight symptoms in coffee genotypes with the SH1 rust resistance gene. New Phytol. 2017, 213, 1315-1329. [CrossRef]

79. Sharma, A.; Jones, J.B.; White, F.F. Recent advances in developing disease resistance in plants. F1000Research 2019, 8, 1-8. [CrossRef]

80. Alvarado, G.; Combes, M.C.; Romero, G.; Lashermes, P. Genetic analysis of partial resistance to coffee leaf rust (Hemileia vastatrix Berk \& Br.) introgressed into the cultivated Coffea arabica L. from the diploid C. canephora species. Euphytica 2009, $167,57-67$. [CrossRef]

81. Romero, G.; Alvarado, G.; Ligarreto, G.; Galeano, N.F. Partial resistance to leaf rust (Hemileia vastatrix) in coffee (Coffea arabica L.): Genetic analysis and molecular characterization of putative candidate genes. Mol. Breed. 2010, 25, 685-697. [CrossRef]

82. Castillo, Z.P.; Alvarado, A.G. Resistencia incompleta de genotipos de café a la roya bajo condiciones de campo en la región central de Colombia. Cenicafé 1997, 48, 40-58.

83. Toniutti, L.; Breitler, J.C.; Etienne, H.; Campa, C.; Doulbeau, S.; Urban, L.; Lambot, C.; Pinilla, J.C.H.; Bertrand, B. Influence of environmental conditions and genetic background of Arabica coffee (C. arabica $\mathrm{L})$ on leaf rust (Hemileia vastatrix) pathogenesis. Front. Plant Sci. 2017, 8, 2025. [CrossRef]

84. Lashermes, P.; Combes, M.C.; Ribas, A.; Cenci, A.; Mahé, L.; Etienne, H. Genetic and physical mapping of the SH3 region that confers resistance to leaf rust in coffee tree (Coffea arabica L.). Tree Genet. Genomes 2010, 6, 973-980. [CrossRef]

85. Ribas, A.F.; Cenci, A.; Combes, M.C.; Etienne, H.; Lashermes, P. Organization and molecular evolution of a disease-resistance gene cluster in coffee trees. BMC Genom. 2011, 12, 240. [CrossRef]

86. Prakash, N.S.; Marques, D.V.; Varzea, V.M.P.; Silva, M.C.; Combes, M.C.; Lashermes, P. Introgression molecular analysis of a leaf rust resistance gene from Coffea liberica into C. arabica L. Theor. Appl. Genet. 2004, 109, 1311-1317. [CrossRef] [PubMed]

87. Mahé, L.; Combes, M.C.; Várzea, V.M.P.; Guilhaumon, C.; Lashermes, P. Development of sequence characterized DNA markers linked to leaf rust (Hemileia vastatrix) resistance in coffee (Coffea arabica L.). Mol. Breed. 2008, 21, 105-113. [CrossRef]

88. Romero, G.; Vásquez, L.M.; Lashermes, P.; Herrera, J.C. Identification of a major QTL for adult plant resistance to coffee leaf rust (Hemileia vastatrix) in the natural Timor hybrid (Coffea arabica $\times$ C. canephora). Plant Breed. 2014, 133, 121-129. [CrossRef]

89. de Brito, G.G.; Caixeta, E.T.; Gallina, A.P.; Zambolim, E.M.; Zambolim, L.; Diola, V.; Loureiro, M.E. Inheritance of coffee leaf rust resistance and identification of AFLP markers linked to the resistance gene. Euphytica 2010, 173, 255-264. [CrossRef]

90. Diola, V.; de Brito, G.G.; Caixeta, E.T.; Maciel-Zambolim, E.; Sakiyama, N.S.; Loureiro, M.E. High-density genetic mapping for coffee leaf rust resistance. Tree Genet. Genomes 2011, 7, 1199-1208. [CrossRef]

91. Pestana, K.N.; Capucho, A.S.; Caixeta, E.T.; de Almeida, D.P.; Zambolim, E.M.; Cruz, C.D.; Zambolim, L.; Pereira, A.A.; de Oliveira, A.C.B.; Sakiyama, N.S. Inheritance study and linkage mapping of resistance loci to Hemileia vastatrix in Híbrido de Timor UFV 443-03. Tree Genet. Genomes 2015, 11, 72. [CrossRef]

92. Alkimim, E.R.; Caixeta, E.T.; Sousa, T.V.; Pereira, A.A.; de Oliveira, A.C.B.; Zambolim, L.; Sakiyama, N.S. Marker-assisted selection provides arabica coffee with genes from other Coffea species targeting on multiple resistance to rust and coffee berry disease. Mol. Breed. 2017, 37, 6. [CrossRef]

93. Almeida, D.P.; Caixeta, E.T.; Moreira, K.F.; de Oliveira, A.C.B.; de Freitas, K.N.P.; Pereira, A.A.; Rosado, R.D.S.; Zambolim, L.; Cruz, C.D. Marker-assisted pyramiding of multiple disease resistance genes in coffee genotypes (Coffea arabica). Agronomy 2021, 11, 1763. [CrossRef]

94. Sousa, T.V.; Caixeta, E.T.; Alkimim, E.R.; Oliveira, A.C.B.; Pereira, A.A.; Sakiyama, N.S.; Zambolim, L.; Resende, M.D.V. Early selection enabled by the implementation of genomic selection in Coffea arabica breeding. Front. Plant Sci. 2019, 9, 1934. [CrossRef]

95. Cui, L.; Hanika, K.; Visser, R.G.F.; Bai, Y. Improving pathogen resistance by exploiting plant susceptibility genes in coffee (Coffea spp.). Agronomy 2020, 10, 1928. [CrossRef]

96. Narasimhaswamy, R.L. Arabica selection S. 795. Its origin and performance: A study. Indian Coffee 1960, 24, 197-204.

97. Srinivasan, K.H.; Narasimhaswamy, R.L. A review of coffee breeding work done at the Government coffee experiment station, Balehonnur. Indian Coffee 1975, 34, 311-321.

98. Bettencourt, A.J.; Rodrigues, C.J.; Lopes, J. Study of the physiologic specialization of the coffee rust Hemileia vastatrix B.\&Br. and selection of coffee clones for the establishment of a standard range of differential hosts for this rust. In Progress Report 1960-1965; Instituto de Investigação Científica Tropical (IICT): Oeiras, Portugal, 1965; pp. 28-46.

99. Capot, J.L. L' amélioration du caféir en Côte dÍvoire. Les Lybrides “Arabustas." Café Cacao Thé 1972, 19, 13-18. 
100. Carvalho, A.; Eskes, A.B.; Fazuoli, L.C. Breeding coffee for rust resistance in Bazil. In Coffee Rust: Epidemiology, Resistance and Management; Kushalappa, A.C., Eskes, A.B., Eds.; CRC Press: Boca Raton, FL, USA, 1989; pp. 295-307.

101. Cambrony, H. Arabusta and other interspecific fertile hybrids. In Coffee Agronomy; Clarke, R.J., Macrae, R., Eds.; Elsevier Applied Science Publishers LTD: London, UK, 1988; Volume 4, pp. 263-291.

102. Sreenivasan, M.S. Breeding coffee for leaf rust resistance in India. In Coffee Rust: Epidemiology, Resistance and Management; Kushalappa, A., Eskes, A.B., Eds.; CRC Press: Boca Raton, FL, USA, 1989; pp. 316-323.

103. Mahé, L.; Várzea, V.; Le Pierres, D.; Combes, M.C.; Lashermes, P. A new source of resistance against coffee leaf rust from New-Caledonian natural interspecific hybrids between Coffea arabica and Coffea canephora. Plant Breed. 2007, 126, 638-641. [CrossRef]

104. Krug, C.; DePoerck, R. World coffee survey. In FAO Agricultural Studies N ${ }^{\circ} 76$; Food and Agriculture Organization of the United Nations (FAO): Rome, Italy, 1968.

105. Bettencourt, A.J. Considerações gerais sobre o 'Híbrido de Timor'. Circular 1973, 23, 1-20.

106. Gonçalves, M.M.; Rodrigues, M.L.; Daehnhardt, E. Estudos sobre o café de Timor I. A Hemileia vastatrix B. \& Br. no território e o melhoramento da cafeicultura face à doença. Comum. Miss. Est. Agron. Ultramar 1976, 86, 1-29.

107. Bettencourt, A.J. Melhoramento genético do cafeeiro. Transferência de factores de resistência à $H$. vastatrix Berk \& Br. para as principais cultivares de Coffea arabica L. Ph.D. Thesis, Universidade de Lisboa, Lisboa, Portugal, 1981.

108. Carvalho, A. Principles and practice of coffee plant breeding for productivity and quality factors: Coffea arabica. In Coffee Agronomy; Clarke, R.J., Macrae, R., Eds.; Elsevier Applied Science Publishers LTD: London, UK, 1988; Volume 4, pp. 129-165.

109. Sera, G.; Sera, T.; Fonseca, I.C.B.; Ito, D.S. Resistance to leaf rust in coffee cultivars. Coffee Sci. 2010, 5, 59-66.

110. Carvalho, C.H. Cultivares de Café; Carvalho, C.H., Ed.; Embrapa: Brasília, Brasil, 2007.

111. Arabica Coffee Varieties. Available online: https://varieties.worldcoffeeresearch.org/varieties (accessed on 20 December 2021).

112. Sera, G.H.; Carvalho, C.H.S.; Abrahão, J.C.; Pozza, E.A.; Matiello, J.B.; Almeida, S.R.; Bartelega, L. Coffee leaf rust in Brazil: Historical events, current situation, and control measures. Agronomy 2021. submitted.

113. Jayarama, D. Chandragiri-farmer friendly new Arabica plant variety. Indian Coffee 2007, 71, 21-25.

114. Bertrand, B.; Etienne, H.; Cilas, C.; Charrier, A.; Baradat, P. Coffea arabica hybrid performance for yield, fertility and bean weight. Euphytica 2005, 141, 255-262. [CrossRef]

115. Marie, L.; Abdallah, C.; Campa, C.; Courtel, P.; Bordeaux, M.; Navarini, L.; Lonzarich, V.; Bosselmann, A.S.; Turreira-García, N.; Alpizar, E.; et al. $\mathrm{G} \times \mathrm{E}$ interactions on yield and quality in Coffea arabica: New F1 hybrids outperform American cultivars. Euphytica 2020, 216, 78. [CrossRef]

116. Alvarado, A.G.; Posada-Suárez, H.E.; Cortina-Guerrero, H.A. Castillo: Nueva variedad de café con resistencia a la roya. Av. Tec. Cenicafé 2005, 337, 1-8.

117. Castillo, Z.; Moreno, L. La Variedad Colombia: Selección de un Cultivar Compuesto Resistente a la Roya del Cafeto; Cenicafé: Chinchiná, Colombia, $1987 ; 169 p$

118. Florez, C.; Londoño, C.E.; Guerrero, H.A.; Moncada, M.; Restrepo, E.C.; Ruales, L.N.; Muñoz, C.A.; Rendón, J.R.; Orrego, H. Nueva variedad de porte bajo, altamente productiva, resistente à la roya y al CBD con mayor calidad física del grano. Av. Tec. Cenicafé 2016, 469, 1-8.

119. Gichimu, B.; Gichuru, E.; Mamati, G.; Nyende, A. Occurrence of Ck-1 gene conferring resistance to Coffee Berry Disease in Coffea arabica cv. Ruiru 11 and its parental genotypes. J. Agric. Crop Res. 2014, 2, 51-61.

120. Opile, W.; Agwanda, C. Propagation and distribution of cultivar Ruiru 11. Kenya Coffee 1993, 58, 1496-1508.

121. Pereira, A.A.; Carvalho, G.; Moura, W.M.; Botelho, C.E.; Rezende, J.C.; Oliveira, A.C.B.; Silva, F.L. Cultivares, origens e suas características. In Café Arábica do Plantio à Colheita; Reis, P.R., Cunha, R., Eds.; EPAMIG: Lavras, Brasil, 2010; Volume 1, pp. 163-221, ISBN 978-85-99764-14-5.

122. Eskes, A.B.; Leroy, T. Coffee Selection and Breeding; Wintgens, J.N., Ed.; Wiley-VCH Verlag GmbH \& Co. KGaA.: Weinheim, Germany, 2004. [CrossRef]

123. Chaves, G.M. Melhoramento do cafeeiro visando a obtenção de cultivares resistentes a Hemileia vastatrix Berk. et Br. Rev. Ceres 1976, 23, 321-332.

124. Bertrand, B.; Aguillar, G.; Santacreo, R.; Anzuelo, F. El Mejoramiento Genético en América Central. In Desafios de la Cafeicultura Centroamérica; Bertrand, B., Rapidel, B., Eds.; PROMECAFÉ, CIRAD: Paris, France; IRD, CCCR, IICA: San José, Costa Rica, 1999; pp. 407-456.

125. Bettencourt, A.J. Características agronómicas de selecções derivados de cruzamentos entre Híbrido de Timor e as variedades Caturra, Villa Sarchi e Catuaí. In Proceedings of the Comunicações Simpósio sobre Ferrugens do Cafeeiro; Centro de Investigação das Ferrugens do Cafeeiro: Oeiras, Portugal, 1983; pp. 351-374.

126. Bettencourt, A.J.; Fazuoli, L. Melhoramento genético de Coffea arabica L.: Transferência de genes de resistência a Hemileia vastatrix do Híbrido de Timor para a cultivar Villa Sarchí de Coffea. Inst. Agron. Camp. 2008, 84, 1-20.

127. Matiello, J.; Almeida, S.; Ferreira, I.; Carvalho, C.H. Available online: http://sindicafe-mg.com.br/posts/variedades-de-caferesistentes-sao-vantajosas (accessed on 16 November 2021).

128. van der Vossen, H.A.M.; Walyaro, D.J. Additional evidence for oligogenic inheritance of durable host resistance to coffee berry disease (Colletotrichum kahawae) in arabica coffee (Coffea arabica L.). Euphytica 2009, 165, 105-111. [CrossRef] 
129. Ito, D.; Sera, T.; Sera, G.; Del Grossi, L.; Kanayama, F. Resistance to bacterial blight in arabica coffee cultivars. Crop Breed. Appl. Biot. 2008, 8, 99-103. [CrossRef]

130. Lashermes, P. Breeding tools for durable resistance to nematodes (Meloidogyne spp.) of coffee varieties. Plant Prot. Sci. 2002, 38, 717-720. [CrossRef]

131. Petek, M.; Sera, T.; Sera, G.; Fonseca, I.C.; Ito, D. Selection of progenies of Coffea arabica with simultaneous resistance to bacterial blight and leaf rust. Bragantia 2006, 65, 65-73. [CrossRef]

132. Rezende, R.; Salgado, S.M.; Rezende, J.; Carvalho, G.; Pereira, A.; Lima, R.; Ferreira, A. Resistência de progênies de Coffea arabica em área infestada por Meloidogyne exigua. Nematropica 2013, 43, 233-240.

133. Bertrand, B.; Anthony, F.; Lashermes, P. Breeding for resistance to Meloidogyne exigua in Coffea arabica by introgression of resistance genes of Coffea canephora. Plant Pathol. 2001, 50, 637-643. [CrossRef]

134. Melo, G.A.; Shimizu, M.M.; Mazzafera, P. Polyphenoloxidase activity in coffee leaves and its role in resistance against the coffee leaf miner and coffee leaf rust. Phytochemistry 2006, 67, 277-285. [CrossRef]

135. Reichel, T.; de Resende, M.L.V.; Monteiro, A.C.A.; Freitas, N.C.; dos Santos Botelho, D.M. Constitutive defense strategy of coffee under field conditions: A comparative assessment of resistant and susceptible cultivars to rust. Mol. Biotechnol. 2021. [CrossRef]

136. Silva, M.C.; Guerra-Guimarães, L.; Loureiro, A.; Nicole, M.R. Involvement of peroxidases in the coffee resistance to orange rust (Hemileia vastatrix). Physiol. Mol. Plant Pathol. 2008, 72, 29-38. [CrossRef]

137. Silva, M.C.; Nicole, M.; Guerra-Guimarães, L.; Rodrigues, C.J. Hypersensitive cell death and post-haustorial defence responses arrest the orange rust (Hemileia vastatrix) growth in resistant coffee leaves. Physiol. Mol. Plant Pathol. 2002, 60, 169-183. [CrossRef]

138. Ganesh, D.; Petitot, A.S.; Silva, M.C.; Alary, R.; Lecouls, A.C.; Fernandez, D. Monitoring of the early molecular resistance responses of coffee (Coffea arabica L.) to the rust fungus (Hemileia vastatrix) using real-time quantitative RT-PCR. Plant Sci. 2006, 170, 1045-1051. [CrossRef]

139. Guerra-Guimarães, L.; Cardoso, S.; Martins, I.; Loureiro, A.; Bernardes, S.A.; Várzea, V.; Silva, M.C. Differential induction of superoxide dismutase in Coffea arabica-Hemileia vastatrix interactions. In Proceedings of the 22th International Conference on Coffee Science (ASIC), Campinas, Brazil, 14-19 September 2008; pp. 1036-1039.

140. Diniz, I.; Talhinhas, P.; Azinheira, H.G.; Várzea, V.; Medeira, C.; Maia, I.; Petitot, A.-S.; Nicole, M.; Fernandez, D.; Silva, M.C. Cellular and molecular analyses of coffee resistance to Hemileia vastatrix and nonhost resistance to Uromyces vignae in the resistance-donor genotype HDT832/2. Eur. J. Plant Pathol. 2012, 133, 141-157. [CrossRef]

141. Guerra-Guimarães, L.; Tenente, R.; Pinheiro, C.; Chaves, I.; Silva, M.D.; Cardoso, F.M.H.; Planchon, S.; Barros, D.R.; Renaut, J.; Ricardo, C.P. Proteomic analysis of apoplastic fluid of Coffea arabica leaves highlights novel biomarkers for resistance against Hemileia vastatrix. Front. Plant Sci. 2015, 6, 478. [CrossRef]

142. Diniz, I.; Figueiredo, A.; Sebastiana, M.; Munoz-Pajarez, A.J.; Valverde, J.; Azevedo, H.; Rodrigues, A.S.; Prakash, R.S.; Pereira, A.P.; Guerra-Guimarães, L.; et al. First steps on the resistance profiling of Kawisari coffee hybrid through cytological and gene expression analyses. In Proceedings of the 28th International Conference on Coffee Science (ASIC), Montpellier, France, 28 June-1 July 2021; p. 60.

143. Ramiro, D.; Escoute, J.; Petitot, A.S.; Nicole, M.; Maluf, M.P.; Fernandez, D. Biphasic haustorial differentiation of coffee rust (Hemileia vastatrix race II) associated with defence responses in resistant and susceptible coffee cultivars. Plant Pathol. 2009, 58, 944-955. [CrossRef]

144. Silva, M.C.; Loureiro, A.; Guerra-Guimarães, L.; Nicole, M.; Valente, P.; Rodrigues, C.J., Jr. Active oxygen metabolism in the hypersensitive response of coffee-rust interaction. In Proceedings of the 11th Congress of the Mediterranean Phytopathological Union and 3rd Congress of the Sociedade Portuguesa de Fitopatologia, Évora, Portugal, 17-20 September 2001; pp. 346-348.

145. Sá, M.; Ferreira, J.P.; Queiroz, V.T.; Vilas-Boas, L.; Silva, M.C.; Almeida, M.H.; Guerra-Guimarães, L.; Bronze, M.R. A liquid chromatography/electrospray ionisation tandem mass spectrometry method for the simultaneous quantification of salicylic, jasmonic and abscisic acids in Coffea arabica leaves. J. Sci. Food Agric. 2014, 94, 529-536. [CrossRef]

146. Meyer, D.; Pajonk, S.; Micali, C.; O'Connell, R.; Schulze-Lefert, P. Extracellular transport and integration of plant secretory proteins into pathogen-induced cell wall compartments. Plant J. 2009, 57, 986-999. [CrossRef]

147. Guerra-Guimarães, L.; Silva, M.C.; Struck, C.; Loureiro, A.; Nicole, M.; Rodrigues, C.J.; Ricardo, C.P.P. Chitinases of Coffea arabica genotypes resistant to orange rust Hemileia vastatrix. Biol. Plant. 2009, 53, 702-706. [CrossRef]

148. Maxemiuc-Naccache, V.; Braga, M.R.; Dietrich, S.M.C. Chitinase and beta-1,3-glucanase changes in compatible and incompatible combinations between coffee leaf disks and coffee rust (Hemileia vastatrix). Rev. Bras. Bot. 1992, 15, 145-150.

149. Slusarenko, A.J. The role of lipoxygenase in plant resistance to infection. In Lipoxygenase and Lipoxygenase Pathway Enzymes; AOCS Press: Champaign, IL, USA, 1996; pp. 176-197.

150. Fernandez, D.; Santos, P.; Agostini, C.; Bon, M.C.; Petitot, A.S.; Silva, M.C.; Guerra-Guimarães, L.; Ribeiro, A.; Argout, X.; Nicole, M. Coffee (Coffea arabica L.) genes early expressed during infection by the rust fungus (Hemileia vastatrix). Mol. Plant Pathol. 2004, 5, 527-536. [CrossRef]

151. Florez, J.C.; Mofatto, L.S.; do Livramento Freitas-Lopes, R.; Ferreira, S.S.; Zambolim, E.M.; Carazzolle, M.F.; Zambolim, L.; Caixeta, E.T. High throughput transcriptome analysis of coffee reveals prehaustorial resistance in response to Hemileia vastatrix infection. Plant Mol. Biol. 2017, 95, 607-623. [CrossRef]

152. Diola, V.; Brito, G.G.; Caixeta, E.T.; Pereira, L.F.P.; Loureiro, M.E. A new set of differentially expressed signaling genes is early expressed in coffee leaf rust race II incompatible interaction. Funct. Integr. Genom. 2013, 13, 379-389. [CrossRef] 
153. Guzzo, S.D.; Harakava, R.; Tsai, S.M. Identification of coffee genes expressed during systemic acquired resistance and incompatible interaction with Hemileia vastatrix. J. Phytopathol. 2009, 157, 625-638. [CrossRef]

154. Couttolenc-Brenis, E.; Carrión, G.L.; Villain, L.; Ortega-Escalona, F.; Ramírez-Martínez, D.; Mata-Rosas, M.; Méndez-Bravo, A. Prehaustorial local resistance to coffee leaf rust in a Mexican cultivar involves expression of salicylic acid-responsive genes. PeerJ 2020, 2020, e8345. [CrossRef]

155. Ramiro, D.; Jalloul, A.; Petitot, A.S.; Grossi de Sá, M.F.; Maluf, M.P.; Fernandez, D. Identification of coffee WRKY transcription factor genes and expression profiling in resistance responses to pathogens. Tree Genet. Genomes 2010, 6, 767-781. [CrossRef]

156. Petitot, A.S.; Lecouls, A.C.; Fernandez, D. Sub-genomic origin and regulation patterns of a duplicated WRKY gene in the allotetraploid species Coffea arabica. Tree Genet. Genomes 2008, 4, 379-390. [CrossRef]

157. Petitot, A.S.; Barsalobres-Cavallari, C.; Ramiro, D.; Albuquerque Freire, E.; Etienne, H.; Fernandez, D. Promoter analysis of the WRKY transcription factors CaWRKY1a and CaWRKY1b homoeologous genes in coffee (Coffea arabica). Plant Cell Rep. 2013, 32, 1263-1276. [CrossRef]

158. Niks, R.E.; Rubiales, D. Potentially durable resistance mechanisms in plants to specialised fungal pathogens. Euphytica 2002, 124, 201-216. [CrossRef]

159. Vaz-Patto, M.C.; Rubiales, D. Unveiling common responses of Medicago truncatula to appropriate and inappropriate rust species. Front. Plant Sci. 2014, 5, 618. [CrossRef]

160. Barka, G.D.; Caixeta, E.T.; de Almeida, R.F.; Alvarenga, S.M.; Zambolim, L. Differential expression of molecular rust resistance components have distinctive profiles in Coffea arabica-Hemileia vastatrix interactions. Eur. J. Plant Pathol. 2017, 149, 543-561. [CrossRef]

161. Santos, D. Comparative Analysis of 454 Pyrosequencing Data from Coffee Transcriptomes. Master's Thesis, Universidade de Lisboa, Lisboa, Portugal, 2011.

162. Tang, D.; Wang, G.; Zhou, J.M. Receptor kinases in plant-pathogen interactions: More than pattern recognition. Plant Cell 2017, 29, 618-637. [CrossRef]

163. Knepper, C.; Savory, E.A.; Day, B. The role of NDR1 in pathogen perception and plant defense signaling. Plant Signal. Behav. 2011, 6, 1114-1116. [CrossRef] [PubMed]

164. Cacas, J.L.; Petitot, A.S.; Bernier, L.; Estevan, J.; Conejero, G.; Mongrand, S.; Fernandez, D. Identification and characterization of the Non-race specific Disease Resistance 1 (NDR1) orthologous protein in coffee. BMC Plant Biol. 2011, 11, 144. [CrossRef] [PubMed]

165. McNeece, B.T.; Pant, S.R.; Sharma, K.; Niruala, P.; Lawrence, G.W.; Klink, V.P. A Glycine max homolog of Non-race specific Disease Resistance 1 (NDR1) alters defense gene expression while functioning during a resistance response to different root pathogens in different genetic backgrounds. Plant Physiol. Biochem. 2017, 114, 60-71. [CrossRef] [PubMed]

166. Bouché, N.; Yellin, A.; Snedden, W.A.; Fromm, H. Plant-specific calmodulin-binding proteins. Annu. Rev. Plant Biol. 2005, 56, 435-466. [CrossRef]

167. Aldon, D.; Mbengue, M.; Mazars, C.; Galaud, J.P. Calcium signalling in plant biotic interactions. Int. J. Mol. Sci. 2018, 19, 665. [CrossRef]

168. Jagodzik, P.; Tajdel-Zielinska, M.; Ciesla, A.; Marczak, M.; Ludwikow, A. Mitogen-activated protein kinase cascades in plant hormone signaling. Front. Plant Sci. 2018, 9, 1387. [CrossRef]

169. Krysan, P.J.; Colcombet, J. Cellular complexity in MAPK signaling in plants: Questions and emerging tools to answer them. Front. Plant Sci. 2018, 871, 1674. [CrossRef]

170. Phukan, U.J.; Jeena, G.S.; Shukla, R.K. WRKY transcription factors: Molecular regulation and stress responses in plants. Front. Plant Sci. 2016, 7, 760. [CrossRef]

171. Wani, S.H.; Anand, S.; Singh, B.; Bohra, A.; Joshi, R. WRKY transcription factors and plant defense responses: Latest discoveries and future prospects. Plant Cell Rep. 2021, 40, 1071-1085. [CrossRef]

172. Bari, R.; Jones, J.D.G. Role of plant hormones in plant defence responses. Plant Mol. Biol. 2009, 69, 473-488. [CrossRef]

173. Barsalobre-Cavallari, C.F.; Petitot, A.S.; Severino, F.E.; Maia, I.G.; Fernandez, D. Host response profiling to fungal infection: Molecular cloning, characterization and expression analysis of NPR1 gene from coffee (Coffea arabica). In Microbial pathogens and strategies for combating them: Science, technology and education; Mendez-Vilas, A., Ed.; Formatex Research Center: Badajoz, Spain, 2013; pp. 411-418.

174. Tang, B.; Li, X.; Pu, L.; Zhao, Q.; Cui, X.; Ge, F.; Liu, D. A pathogenesis-related protein 10 gene PnPR10-3 was involved in molecular interaction between Panax notoginseng and Fusarium solani. Australas. Plant Pathol. 2019, 48, 447-456. [CrossRef]

175. Van Loon, L.C.; Rep, M.; Pieterse, C.M.J. Significance of inducible defense-related proteins in infected plants. Annu. Rev. Phytopathol. 2006, 44, 135-162. [CrossRef]

176. Breen, S.; Williams, S.J.; Outram, M.; Kobe, B.; Solomon, P.S. Emerging Insights into the Functions of Pathogenesis-Related Protein 1. Trends Plant Sci. 2017, 22, 871-879. [CrossRef]

177. Daudi, A.; Cheng, Z.; O’Brien, J.A.; Mammarella, N.; Khan, S.; Ausubel, F.M.; Paul Bolwell, G. The apoplastic oxidative burst peroxidase in Arabidopsis is a major component of pattern-triggered immunity. Plant Cell 2012, 24, 275-287. [CrossRef]

178. Jwa, N.S.; Hwang, B.K. Convergent evolution of pathogen effectors toward reactive oxygen species signaling networks in plants. Front. Plant Sci. 2017, 8, 1687. [CrossRef] 
179. Mellersh, D.G.; Foulds, I.V.; Higgins, V.J.; Heath, M.C. $\mathrm{H}_{2} \mathrm{O}_{2}$ plays different roles in determining penetration failure in three diverse plant-fungal interactions. Plant J. 2002, 29, 257-268. [CrossRef]

180. Torres, M.A.; Jones, J.D.G.; Dangl, J.L. Reactive oxygen species signaling in response to pathogens. Plant Physiol. 2006, 141, 373-378. [CrossRef]

181. Das, K.; Roychoudhury, A. Reactive oxygen species (ROS) and response of antioxidants as ROS-scavengers during environmental stress in plants. Front. Environ. Sci. 2014, 2, 53. [CrossRef]

182. Hwang, I.S.; Hwang, B.K. The pepper 9-lipoxygenase gene CaLOX1 functions in defense and cell death responses to microbial pathogens. Plant Physiol. 2010, 152, 948-967. [CrossRef]

183. Rojas, M.L.; Montes de Gómez, V.; Ocampo, C.A. Stimulation of lipoxygenase activity in colyledonary leaves of coffee reacting hypersensitively to the coffee leaf rust. Physiol. Mol. Plant Pathol. 1993, 43, 209-219. [CrossRef]

184. Göbel, C.; Feussner, I.; Rosahl, S. Lipid Peroxidation during the hypersensitive response in potato in the absence of 9 Lipoxygenases. J. Biol. Chem. 2003, 278, 52834-52840. [CrossRef]

185. Vermerris, W.; Nicholson, R. Phenolic Compound Biochemistry; Springer Science \& Business Media: Berlin/Heidelberg, Germany, 2006; ISBN 9781402051630.

186. Bagal, U.R.; Leebens-Mack, J.H.; Lorenz, W.W.; Dean, J.F.D. The phenylalanine ammonia lyase (PAL) gene family shows a gymnosperm-specific lineage. BMC Genom. 2012, 13, S1. [CrossRef]

187. Cesarino, I. Structural features and regulation of lignin deposited upon biotic and abiotic stresses. Curr. Opin. Biotechnol. 2019, 56, 209-214. [CrossRef]

188. Campa, C.; Doulbeau, S.; Dussert, S.; Hamon, S.; Noirot, M. Qualitative relationship between caffeine and chlorogenic acid contents among wild Coffea species. Food Chem. 2005, 93, 135-139. [CrossRef]

189. Leitão, S.; Guerra-Guimarães, L.; Bronze, M.R.; Vilas Boas, L.; Sá, M.; Almeida, M.H.G.; Silva, M.C. Chlorogenic acid content in coffee leaves: Possible role in coffee leaf rust resistance. In Proceedings of the 23rd International Conference on Coffee Science (ASIC), Bali, Indonesia, 3-8 October 2010; pp. 743-747.

190. Caillaud, M.C.; Wirthmueller, L.; Sklenar, J.; Findlay, K.; Piquerez, S.J.M.; Jones, A.M.E.; Robatzek, S.; Jones, J.D.G.; Faulkner, C. The plasmodesmal protein PDLP1 localises to haustoria-associated membranes during downy mildew infection and regulates callose deposition. PLoS Pathog. 2014, 10, e1004496. [CrossRef] [PubMed]

191. Conrath, U. Chapter 9 Priming of Induced Plant Defense Responses, 1st ed.; Elsevier Ltd.: Amsterdam, The Netherlands, 2009; Volume 51. [CrossRef]

192. Conrath, U.; Beckers, G.J.M.; Langenbach, C.J.G.; Jaskiewicz, M.R. Priming for Enhanced Defense. Annu. Rev. Phytopathol. 2015, 53, 97-119. [CrossRef] [PubMed]

193. Martins, E.M.F.; Moraes, W.B.C. Development of Hemileia vastatrix in Coffee Plants with Genetic or Induced Resistance. J. Phytopathol. 1996, 144, 519-526. [CrossRef]

194. Guzzo, S.D.; Martins, E.M.F. Local and systemic induction of $\beta$-1,3-glucanase and chitinase in coffee leaves protected against Hemileia vastatrix by Bacillus thuringiensis. J. Phytopathol. 1996, 144, 449-454. [CrossRef]

195. Roveratni, D.S.; Teixeira, A.R.R.; Moraes, W.B.C. Bacillus thuringiensis-A new perspective for an Induced Protection to Coffee Leaf Rust. J. Phytopathol. 1989, 126, 149-159. [CrossRef]

196. Guzzo, S.D.; Bach, E.E.; Martins, E.F.; Moraes, W.C. Crude Exopolysaccharides (EPS) from Xanthomonas campestris pv. manihotis, Xanthomonas campestris pv. Campestris and Commercial Xanthan Gum as Inducers of Protection in Coffee Plants against Hemileia vastatrix. J. Phytopathol. 1993, 139, 119-128. [CrossRef]

197. Henrique, L.; Fernandes, M.; Lúcio, M.; Resende, V.; Pereira, R.; Costa, B.; Monteiro, A.; Júnior, P. Acidenzolar-S-methyl in rust and blotch control in field conditions. Coffee Sci. 2013, 8, 21-29.

198. Carré-Missio, V.; Rodrigues, F.A.; Schurt, D.A.; Resende, R.S.; Souza, N.F.A.; Rezende, D.C.; Moreira, W.R.; Zambolim, L. Effect of foliar-applied potassium silicate on coffee leaf infection by Hemileia vastatrix. Ann. Appl. Biol. 2014, 164, 396-403. [CrossRef]

199. Monteiro, A.C.A.; de Resende, M.L.V.; Valente, T.C.T.; Ribeiro Junior, P.M.; Pereira, V.F.; da Costa, J.R.; da Silva, J.A.G. Manganese phosphite in coffee defence against Hemileia vastatrix, the coffee rust fungus: Biochemical and molecular analyses. J. Phytopathol. 2016, 164, 1043-1053. [CrossRef]

200. Costa, B.H.G.; de Resende, M.L.V.; Ribeiro Júnior, P.M.; Mathioni, S.M.; Pádua, M.A.; da Silva Júnior, M.B. Suppression of rust and brown eye spot diseases on coffee by phosphites and by-products of coffee and citrus industries. J. Phytopathol. 2014, 162, 635-642. [CrossRef]

201. Silva, J.A.G.; Resende, M.L.V.; Monteiro, A.C.A.; Pádua, M.A.; Guerra-Guimarães, L.; Medeiros, F.L.; Martins, S.A.; Botelho, D.M.S. Resistance inducers applied alone or in association with fungicide for the management of leaf rust and brown eye spot of coffee under field conditions. J. Phytopathol. 2019, 167, 430-439. [CrossRef]

202. Possa, K.F.; Silva, J.A.G.; Resende, M.L.V.; Tenente, R.; Pinheiro, C.; Chaves, I.; Planchon, S.; Monteiro, A.C.A.; Renaut, J.; Carvalho, M.A.F.; et al. Primary metabolism is distinctly modulated by plant resistance inducers in Coffea arabica leaves infected by Hemileia vastatrix. Front. Plant Sci. 2020, 11, 309. [CrossRef]

203. De Nardi, B.; Dreos, R.; Del Terra, L.; Martellossi, C.; Asquini, E.; Tornincasa, P.; Gasperini, D.; Pacchioni, B.; Rathinavelu, R.; Pallavicini, A.; et al. Differential responses of Coffea arabica L. leaves and roots to chemically induced systemic acquired resistance. Genome 2006, 49, 1594-1605. [CrossRef] 
204. Fernandes, L.H.M.; de Oliveira Silveira, H.R.; de Souza, K.R.; de Resende, M.L.; Alves, J.D. Inductors of resistance and their role in photosynthesis and antioxidant system activity of coffee seedlings. Am. J. Plant Sci. 2014, 5, 3710-3716. [CrossRef]

205. Resende, M.L.V.; Nojosa, G.B.A.; Cavalcanti, L.S.; Aguilar, M.A.G.; Silva, L.H.C.P.; Perez, J.O.; Andrade, G.C.G.; Carvalho, G.A.; Castro, R.M. Induction of resistance in cocoa against Crinipellis perniciosa and Verticillium dahliae by acibenzolar-S-methyl (ASM). Plant Pathol. 2002, 51, 621-628. [CrossRef]

206. Chaves, I.; Barros, D.R.; Rodrigues, A.; Silva, M.C.; Ricardo, C.P.; Miguel, C.; Guerra-Guimarães, L. Identification of miRNAs as mediators of Coffea arabica resistance to Hemileia vastatrix. In Proceedings of the 25 th International Conference on Coffee Science (ASIC), Armenia, Colombia, 8-13 September 2014; p. 219. 